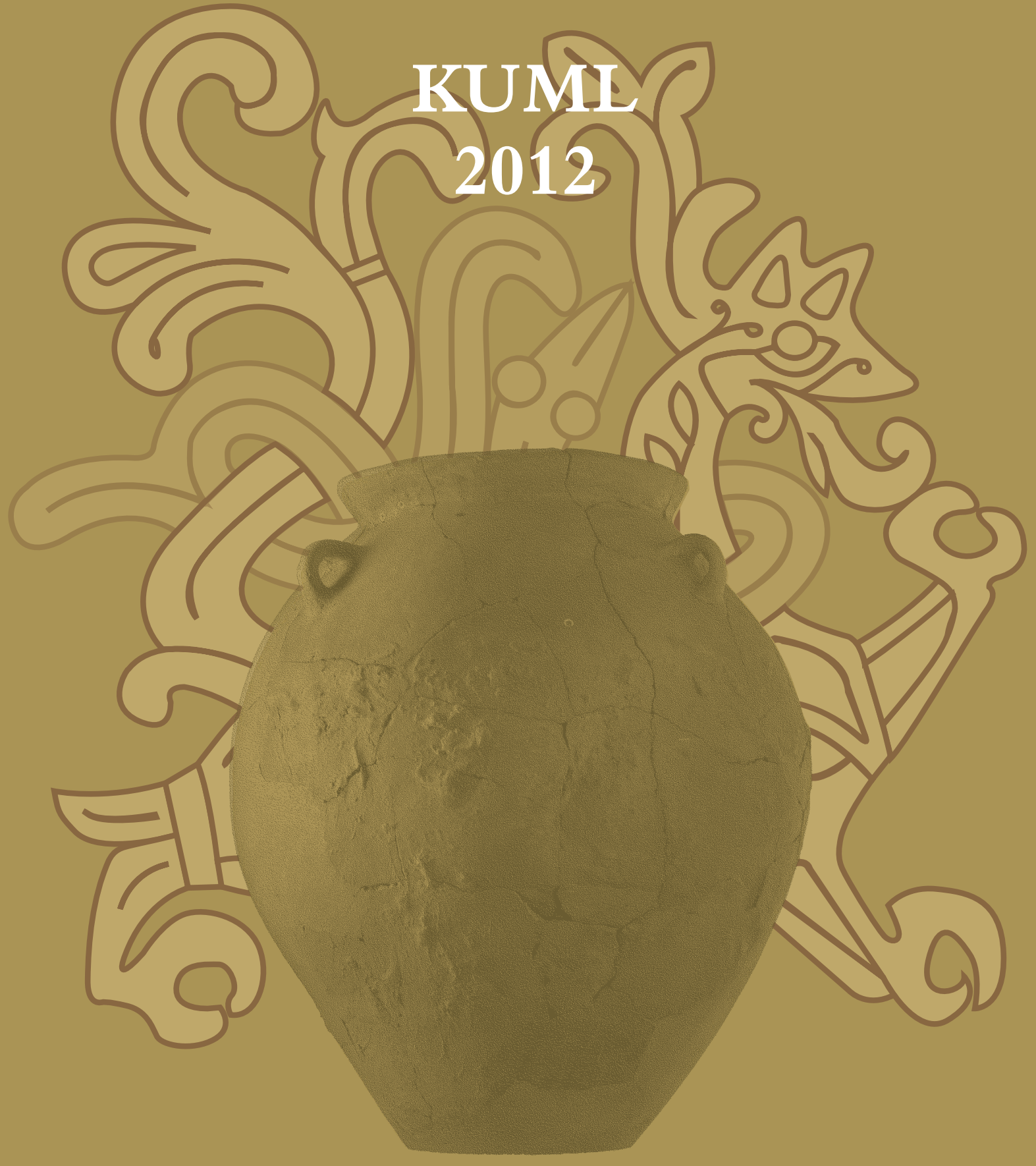




\section{KUML 2012}

Årbog for Jysk Arkæologisk Selskab

With summaries in English

I kommission hos Aarhus Universitetsforlag 


\title{
Alrum \\ Brandtomter i en vestjysk byhøj fra ældre jernalder
}

\author{
Af JØRGEN LUND \& POUL NISSEN
}

I museernes magasiner gemmer sig mange interessante fund, som ikke altid har fået den opmærksomhed, der burde tilkomme dem. ${ }^{1}$ Alrumudgravningen, der skal præsenteres i det følgende, er en sådan. Blandt de undersøgte huse er det især brandtomterne hus I og II, der tiltrækker sig opmærksomhed, og ikke mindst hus II hører til blandt de absolut mest informative fra Danmark. Det skyldes først og fremmest det meget store antal fund af forkullede korn og frø, som også er det, udgravningen specielt er kendt for blandt fagfæller. Man forstår godt, at Gudmund Hatt i sin dagbog skriver: “7. Maj (1939). Udgravningen af Hus II. En ualmindelig god Brandtomt ... store Fund af Korn (Byg, Havre) og Polygonum lapathifolium i Kar." ${ }^{2}$ Det er store ord fra en mand, der havde gravet i og set alt, hvad der var værd at se af jernalderhuse.

At undersøgelsen først fremlægges nu skyldes bl.a., at beretningen længe har været bortkommet, men under oprydning på Nationalmuseets daværende Naturvidenskabelige Afdeling i 2000 dukkede den op, men desværre uden de mange fotos, der refereres til. ${ }^{3}$ Der er dog ingen tvivl om, at Hatt havde planer om at publicere fundet, idet beretningens opbygning følger hans øvrige arbejder. I publikationen af Nr. Fjand fra 1957 beklager Hatt da også, at Alrumudgravningen endnu ikke er offentliggjort.

De mere end 70 år, der er gået, siden udgravningen fandt sted, har naturligvis tæret en del på fundet, og det er især gået ud over det naturvidenskabelige materiale. Mange forkullede træstykker og fund af halmsimer, halm- og græsprøver samt et nøgle garn m.m. er væk eller blevet til støv. Lidt af keramikken mangler ligeledes, men det er uden betydning for dateringen.

Takket være de særdeles omhyggelige beskrivelser og yderst detaljerede plantegninger er det alligevel muligt at få et usædvanligt godt indblik i undersøgelsen. Man forstår, hvorfor Hatt blev anset for en af de bedste feltarkæologer for sin tid. I det konkrete tilfælde skal konservator Hans Helbæk dog have den største del af æren, eftersom han forestod undersøgelsen, idet Hatt grundet 

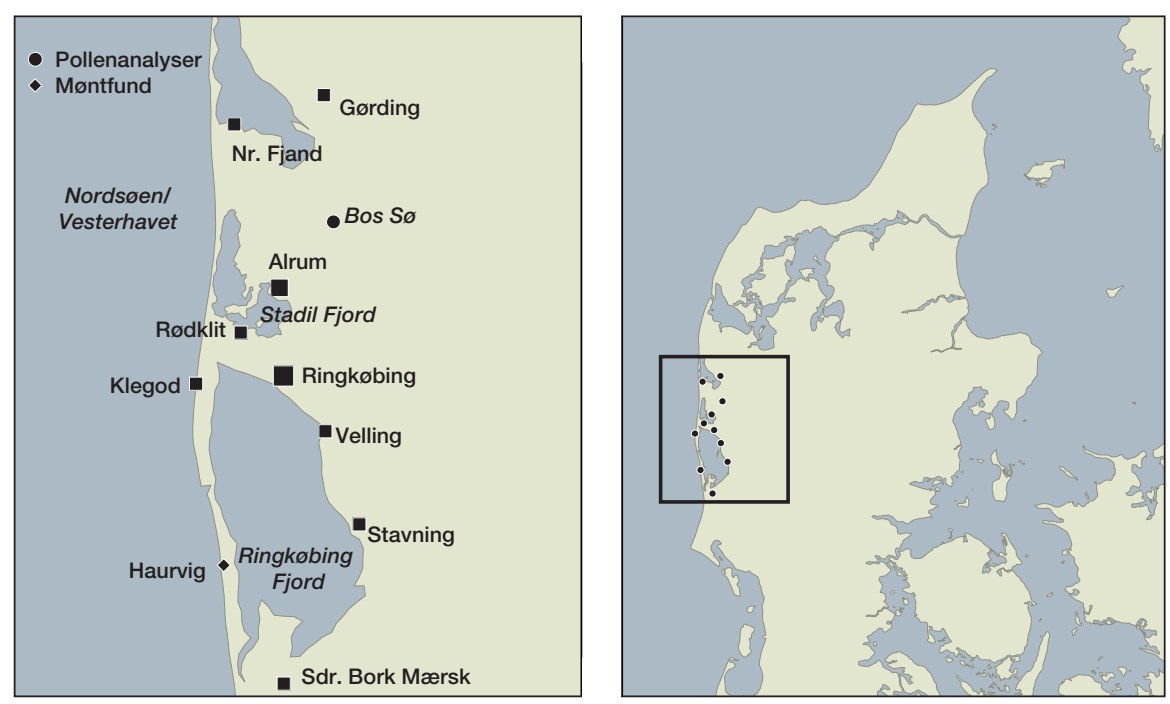

Fig. 1. Jyllandskort med det relevante delområde fremhævet. Stednavnene refererer til teksten.

Map of Jutland highlighting the relevant area and the location of place names mentioned in the text.

sygdom og andre arbejdsopgaver kun havde mulighed for at besøge udgravningen et par gange.

Det følgende er primært tænkt som en fundfremlæggelse af dette gamle, men interessante fund, og med udgangspunkt heri er der anledning til at kommentere en række forhold, som anses for relevante for de jernalderlige bebyggelser i et vestjysk kystzoneområde. Det drejer sig bl.a. om erhvervsforholdene, skovbilledet, kystforløbet og ikke mindst sandflugtens omfang og betydning. Desuden er der gjort forsøg på at vurdere, hvor meget det forkullede hustømmer er mindsket med henblik på at anslå tømmerets oprindelige dimensioner. Endelig skal det nævnes, at Alrumfundet alene vurderes i relation til de samtidige bopladser inden for et mindre regionalområde, som det fremgår af fig. 1, men dog med nogle få udblik til andre lokaliteter nær Nordsøkysten.

\section{Fundhistorie}

Bopladsen ligger ca. $1 \mathrm{~km}$ fra nordøstenden af Stadil Fjord, og ca. $10 \mathrm{~km}$ nord for Ringkøbing. Den er anlagt på en lille flyvesandshøjning, der hæver sig nogle få meter over dansk normalnul. Undersøgelsen kom i gang, fordi ejeren, gdr. Johannes Jensen, var stødt på lerkarskår og aske i forbindelse med gravning 
af et par roekuler, og Ringkøbing Museums daværende leder, landsretssagfører Jens Dalgaard-Knudsen, blev informeret. Gudmund Hatt tilkaldtes, og i løbet af seks uger i april-maj i 1939 undersøgtes et felt på små $300 \mathrm{~m}^{2}$ med ni mere eller mindre bevarede hustomter. På grund af de mange fund af forkullede korn og frø tog han Hans Helbæk med; han var konservator og arkæobotaniker, så de første artsbestemmelser skete på stedet.

I området med den største huskoncentration lå hele 6-7 tomter over hinanden, og dannede et kulturlag på 1,5 meters tykkelse, med andre ord en byhøj. Ardspor nederst viste, at bopladsen var anlagt på en ældre markflade. Det begrænsede udgravningsområde gav desværre ingen muligheder for at bedømme bopladsens udstrækning, men formentlig har den været ganske lille. Lidt vest for det gamle felt viste luftfotografier fra 1992 tydeligt 6-7 hustomter, der afslørede sig ved mørke stolpehulsspor, så her kan der intet kulturlag være. ${ }^{4} \mathrm{Om}$ der er en forbindelse mellem de to dele kan kun afklares ved en udgravning.

\section{Hus II}

Der blev som nævnt påvist ni huse, men de fleste kunne ikke udgraves i deres helhed, da de gik ind i uudgravet område. Husene I og II var nedbrændt og vil blive beskrevet mere detaljeret, mens de øvrige får en kortere omtale (fig. 2).

Det er et langhus, som blev fundet 70-80 cm under markfladen. Tomten, der blev totaludgravet, var ca. 14,5 m lang og med en bredde på 4,5-4,0 m, smallest ved gavlene. Orienteringen var vestnordvest-østsydøst, og dets omrids markeredes af en 10-30 cm bred og 5-20 cm høj lerbræmme, der blev tolket som dele af vægfoden. De ca. $60 \mathrm{~m}^{2}$ under tag var omtrent ligeligt fordelt mellem beboelsen mod vest og den formodede stalddel mod øst. Beboelsen så desuden ud til at have været opdelt $i$ to halvdele markeret med en form for skillevægge vinkelret ud fra ydervæggene (fig. 3).

Huset må være blevet forladt i største hast, og branden synes at have været meget voldsom, idet en del lerkar er stærkt forbrændte og nærmest har antaget skulpturelle former. Temperaturen må derfor have været oppe på 1.000-1.100 grader. ${ }^{5}$ På flere af stenredskaberne ses ligeledes afsprængte partier.

Brandlaget bestod af aske, sand, halmrester, kviste samt store mængder forkullede stykker af egetræ, som især lå koncentreret i midten af huset. I den vestlige del indeholdt brandlaget desuden de mange fund af brændte korn og frø samt et stort lerkarmateriale, dertil kom tre netsynk, to glittesten, et par slibesten og enkelte andre stenoldsager. Østenden var derimod næsten fundtom med undtagelse af fire stærkt forbrændte knoglestumper fra kvæg og fra får eller ged. ${ }^{6}$ Rummet havde jordgulv, som det er sædvanligt i staldene i den periode, 


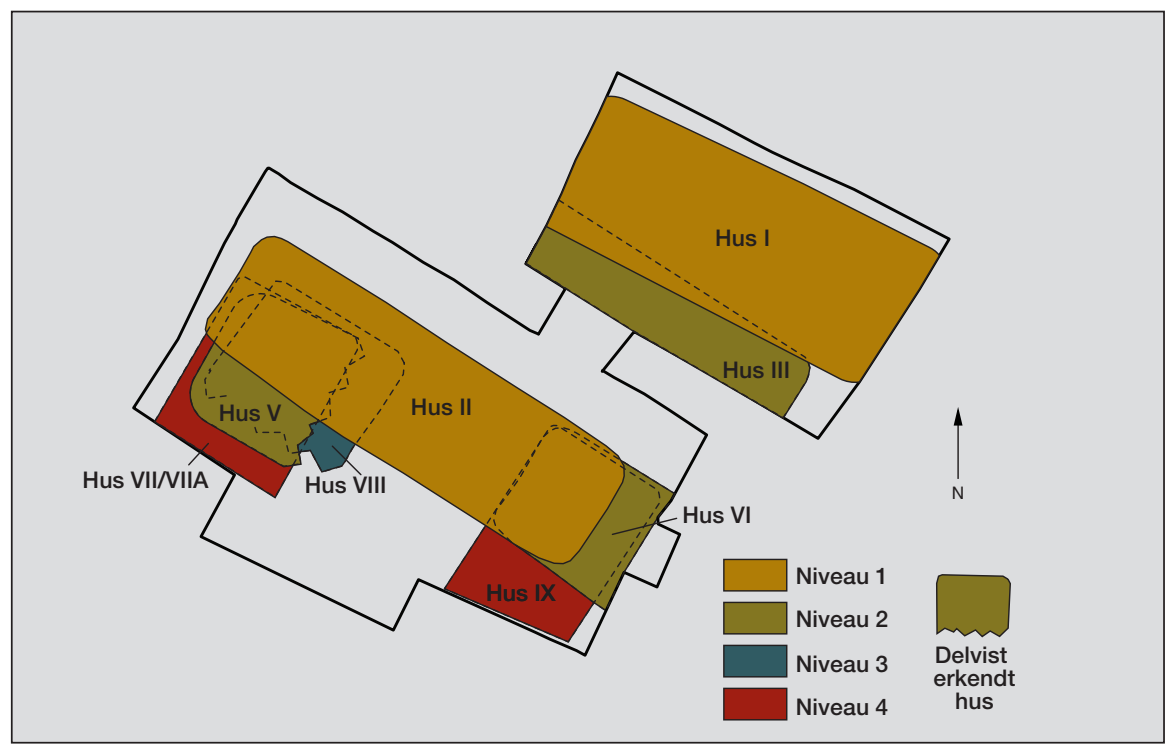

Fig. 2. Oversigtsplan med samtlige huse. - Digitaliseret af Poul Nissen.

Excavation plan showing all the houses (hus I-IX) in four levels (niveau 1-4).

men med den fine bevaringstilstand in mente forekommer det besynderligt, at der ikke var de mindste spor efter båseskillerum, som ellers ofte står tilbage i brandtomter. En umiddelbar tolkning er derfor, at huset kan være nedbrændt, inden stalden er blevet bygget færdig, og der sås heller ingen nedslidninger fra kreaturerne. Men funktionen kan selvfølgelig have været en anden, idet der blev fundet forholdsvis mange op til $10 \mathrm{~cm}$ tykke stykker af det såkaldte paneltræ, som menes at være beklædning på væggenes inderside. Beboelsesdelen var klart markeret af et ujævnt lergulv, der rundede jævnt op til vægfoden.

Fig. 3. Plan af hus II med lerbænk og ildsted med morterstenen liggende midt imellem. De fire store lerkager ses lige vest for lerbænken. A. viser det forkullede træværk, og her skal især bemærkes de mange stykker paneltræ langs væggene. B. afbilder koncentrationer af makrofossiler samt de største klynger af keramik. - Digitaliseret af Poul Nissen.

Plan of house II showing the clay bench or platform and hearth with the stone mortar between them. The four clumps of untempered clay can be seen to the west of the bench. A. shows the charred timbers; note in particular the many pieces of wattle panel along the walls. 1: Horizontal charred wood; 2: Vertical charred wood; 3: Stone; 4: Clay bench or platform; 5: Clay floor. B. shows the concentrations of plant macro-remains and the largest clusters of pottery.1: Lumps of clay; 2: Pottery; 3: Seeds; 4: Barley (conc.); 5: Barley; 6: Oats (conc.); 7: Posthole, pit; 8: Burnt layer; 9: Clay layer. 


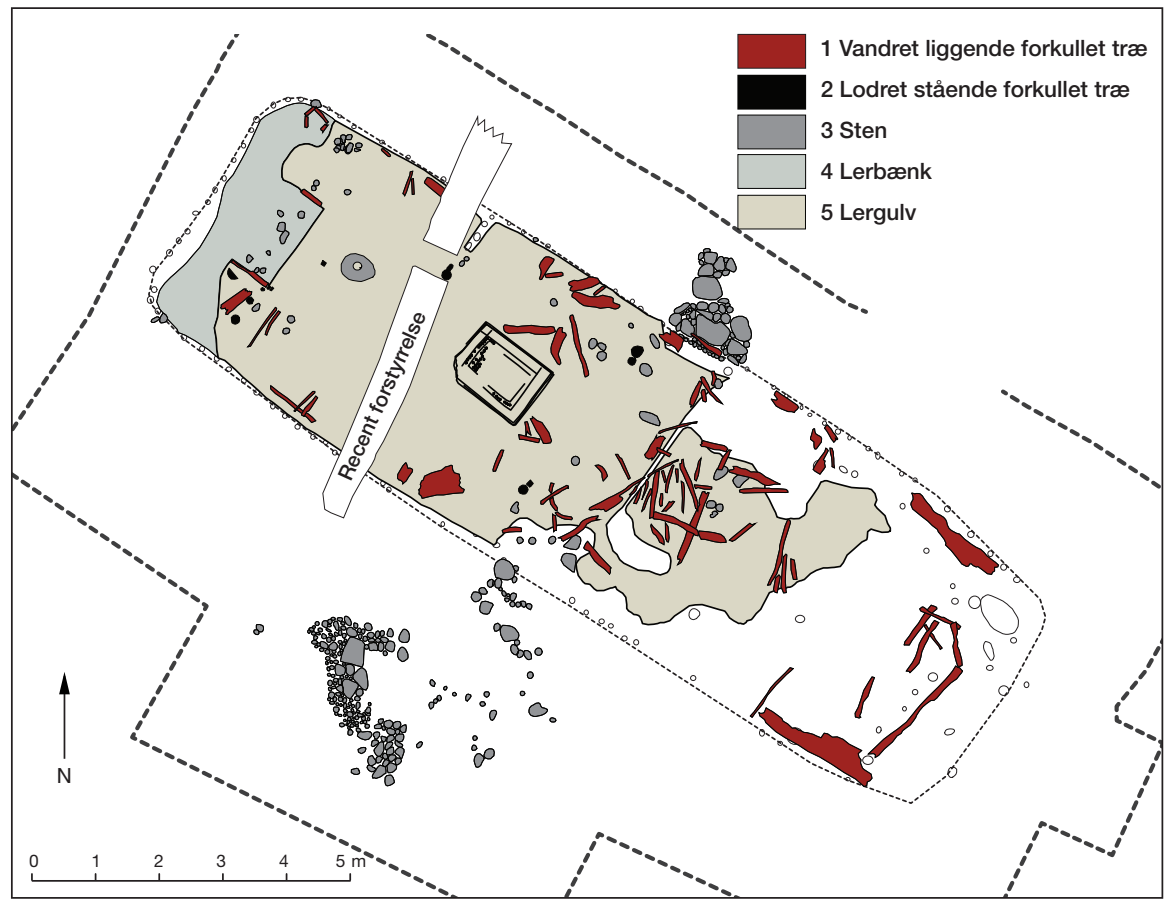

A

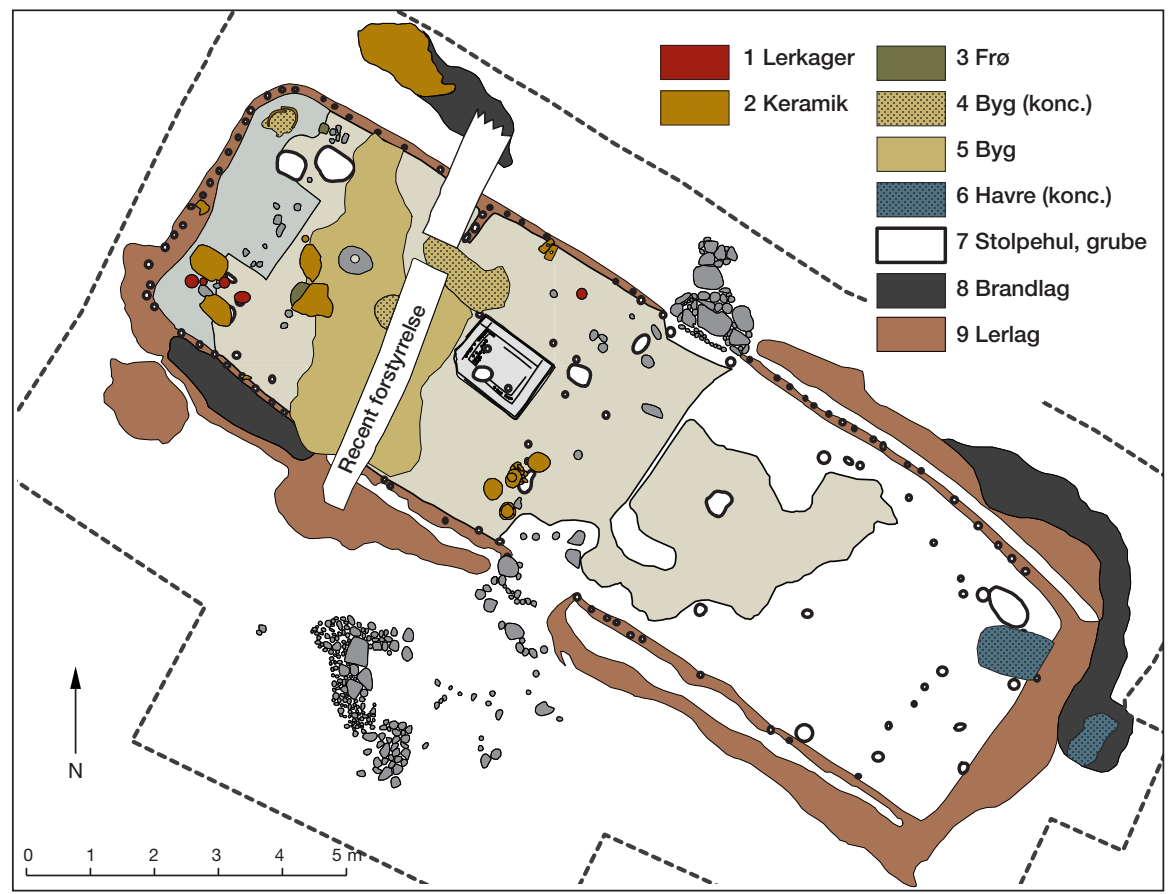

B 
I huset var der to modstående indgange; i den nordlige, som var 1,4 $\mathrm{m}$ bred, lå en stenlægning og dele af et svært dørtrin af egetræ tilbage, mens indgangspartiet mod syd var noget slidt, hvilket vel er et tegn på, at her var hoveddøren.

I mange tomter ses stolpehuller, som viser, at der har været et separat indgangsrum, men i hus II er der kun spor efter en skillevæg ind mod den østlige halvdel, hvor en ca. $4 \mathrm{~cm}$ dyb og 6-7 $\mathrm{cm}$ bred rende menes at have indeholdt et stykke fodtømmer. Fra beboelsesdelen stikker en lertunge ind over jordgulvet, og det må betyde, at der har været en åbning i skillevæggen.

\section{Tagkonstruktion}

Taget har, som det er sædvane, været båret af to rækker egestolper på langs af huset, i alt fem stolpepar. I mange af stolpehullerne stod de forkullede stolpeender tilbage, så dimensionerne kunne måles. De fleste tagstolper i hus II havde været runde, men i tre tilfælde kanthuggede. I flere af hullerne havde der stået to stolper, hvoraf den ene var rund, mens makkeren var kantet.

Det er altid vanskeligt at sige noget om tagmaterialet, men omtrent i husets midtlinje fandtes en stribe, som afveg fra det øvrige brandlag. Den var mere sandet og med "en ejendommelig jord- eller tørveagtig Karakter". ${ }^{7}$ Udgraverne foreslår, at det kunne være rester af møntørven, den tørv, som lægges på tagets rygning. I husets midte lå som nævnt meget forkullet materiale bestående af rafter og grene samt lyng, græs og halm, der vel kunne være en indstyrtet tagdel?

\section{Vægkonstruktion}

I den velbevarede tomt sås de langagtige huller efter vægstolperne meget tydeligt, med undtagelse af den østlige gavlvæg. De målte $5 \times 10 \mathrm{~cm}$ og stod med en ensartet afstand af ca. $25 \mathrm{~cm}$ og med dybder på $15-20 \mathrm{~cm}$. I to tilfælde målte de forkullede kanthuggede egestolper henholdsvis $4 \times 8 \mathrm{~cm}$ og $3 \times 6 \mathrm{~cm}$. Formen på stolpehullerne antyder i øvrigt, at stolperne har haft et rektangulært eller rhombisk tværsnit.

Den 10-30 cm høje og 5-20 cm brede lerbræmme, som angiver husets omrids, skal formentlig forstås som rester efter en dobbeltsidig lerklining, der imidlertid antages kun at have dækket væggenes nederste dele. Måske har der været tale om en form for "træk", som i historisk tid var betegnelsen for en nedre midlertidig beskyttelse af væggen. De flettede vægge har næppe været beklasket højere op, for der er ikke fundet et eneste stykke brændt lerklining. Det menes derfor, at den flettede væg snarere har været forsynet med et indre egetræspanel, igen et velkendt træk ved jernalderens huse. Det understøttes af de mange og store stykker egebrædder, der oftest ligger parallelt med væg- 
gen. De er 4-10 cm tykke og kan være op til $2 \mathrm{~m}$ lange, og mange af stykkerne ligger på en sådan måde, at denne tolkning forekommer sandsynlig (fig. 3). Væggenes ydersider antages derimod at have været beklædt med "et Lag Halm eller Græs, der kan have været fastbundet til Fletvæggen med Simer......, og på grundlag af, at "Rester af Halm- eller Bastsimer blev, som foran omtalt, fundet ét Sted ved Nordvæggen". ${ }^{8}$ Umiddelbart virker det ikke som en særlig effektiv vægbeklædning, når man tager det barske vesterhavsklima i betragtning.

Husets "hjerte" var det rektangulære ildsted, som lå ret i husets midtlinje. Det målte 1,4x1,0 m, og midtpå var det $24 \mathrm{~cm}$ tykt. Det var meget velbevaret med en lerkappe ornamenteret med indstemplede cirkelfigurer. Den centrale del var afgrænset af en firkantet, dobbeltstreget kantning, mellem hvilke der ligeledes var cirkler med en diameter på ca. $3 \mathrm{~cm}$. I dets nedre ubrændte lerlag lå indlejret en stenlægning med to små løbere, 13 knusesten og et par større sten med slidflader. Det er givetvis et offer, som det kendes fra utallige ildsteder, men kan naturligvis også blot være en praktisk foranstaltning. I kort afstand fra ildstedets smalsider fandtes to mindre stolpehuller, og stolperne heri kunne have fungeret som et slags stativ i forbindelse med madlavningen. I det dybereliggende hus $\mathrm{V}$ lå der et rundovalt ildsted, og det bekræfter endnu engang, at denne form er ældst. De dekorerede arneplader er desuden et fænomen, som hovedsageligt optræder i yngre førromersk og ældre romertid. ${ }^{9}$

\section{Lerbænksområdet}

Langs vestgavlen fandtes rester af en lerbænk, hvor de midterste $1,5 \mathrm{~m}$ udgjorde et markant retvinklet fremspring. Den sydlige kant havde formentlig været forstærket med et stykke kraftigt egetræ, som var $60 \mathrm{~cm}$ langt og med et tværsnit på $5 \times 6 \mathrm{~cm}$. Fronten var desuden forsynet med en form for fletværk af tynde kviste af el og pil. ${ }^{10}$ Bænken hævede sig blot ca. $10 \mathrm{~cm}$ over gulvet, og på dens sydvestlige del lå en skubbekværn med tilhørende løber. I det modsatte hjørne ved lerbænken fandtes ikke mindre end fire store kager af umagret pottemagerler, hver med en vægt på godt 9 kg (fig. 4), og nær disse en glittesten, et vigtigt værktøj ved fremstillingen af lerkar.

I gavlområdet har også stået mange og store lerkar, vel hovedsagelig til opbevaring (fig. $5 \mathrm{a}-\mathrm{f}$ ). Denne del af huset har spillet en central rolle i dagliglivets aktiviteter. Fra bænken har det været let at holde øje med ildstedet, og hvad der i øvrigt foregik i rummet, ligesom de vigtigste funktioner er udgået herfra. Dette kan suppleres med, at der i mange thylandske hustomter er fundet nogle meget store beholdere i gavlendens hjørner. De må have haft en særlig funk- 
Fig. 4. Lerkage af umagret ler fra hus II, ca. $30 \times 23 \times 21 \mathrm{~cm}$. - Foto: Martin Ravn Bendtsen, Fotoafdelingen, Moesgård.

Fig. 4. Lump of untempered clay from house II, c. $30 \times 23 \times 21 \mathrm{~cm}$.

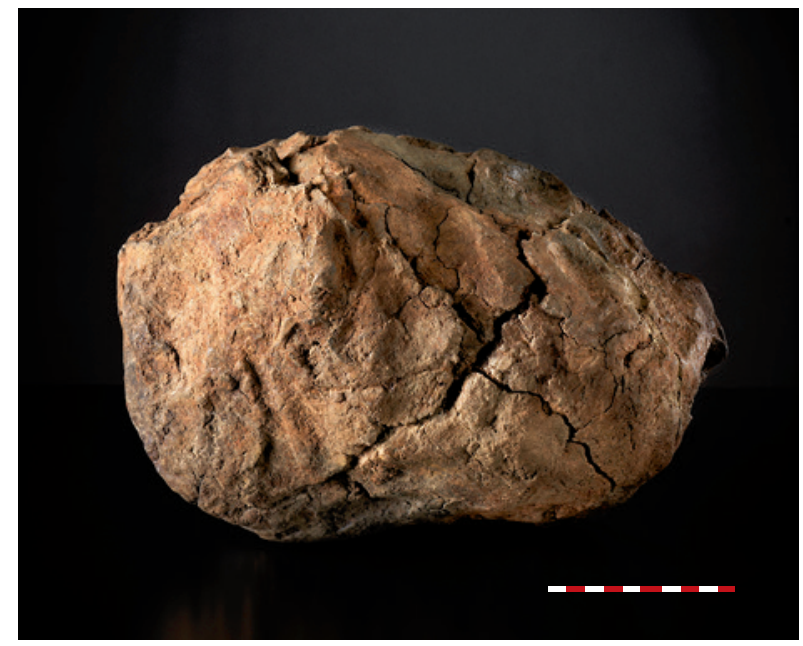

tion, eftersom de oftest er fremstillet af plantemagret ler, og beholdere med den slags karvægge er da også særdeles velegnede til køling af væsker. ${ }^{11}$ Et fund fra Nørhå, ligeledes i Thy, giver desuden et interessant indblik i en endnu mere sofistikeret ruminddeling. I et lille bevaret stykke af gavlområdet i et jernalderhus sås en inddeling med flere små og større rum, som var adskilt af ganske tynde halmvægge beklasket med ler. ${ }^{12}$

Omtrent midt imellem vestgavl og ildsted lå den sædvanlige mortersten gravet ned, så den bare ragede nogle få centimeter op over lergulvet. Den var fremstillet af en udtjent skubbekværn.

\section{Fundene}

Keramikken er næsten enerådende, og i det store materiale indgår mange hele lerkar. Men ellers var indsamlingsprincippet, at man kun tog rand-, bund- og hankeskår samt ornamenterede stykker og særlige fragmenter med hjem.

På grundlag af gennemgangen af samtlige fund registreret i forbindelse med hus II repræsenterer skårene godt 100 forskellige kar; et indlysende for højt antal. Det bedste tegn på, at keramikken hører til hus II, er den sekundære brænding, der kan iagttages på et større antal mere eller mindre hele kar samt på mange af skårene. De mange rand- og hankeskår giver et godt dateringsgrundlag. Randene er oftest let fortykkede og bredt facetterede, mens hankene er mere eller mindre X-formede. Dertil kommer, at mange randskår fra de større og grovere forrådskar er forsynet med pålagte fingerindtrykslister i selve randknækket, hvilket viser, at brandtomten skal dateres til den yngste del af førromersk jernalder, det vil sige århundredet før år 0 . 


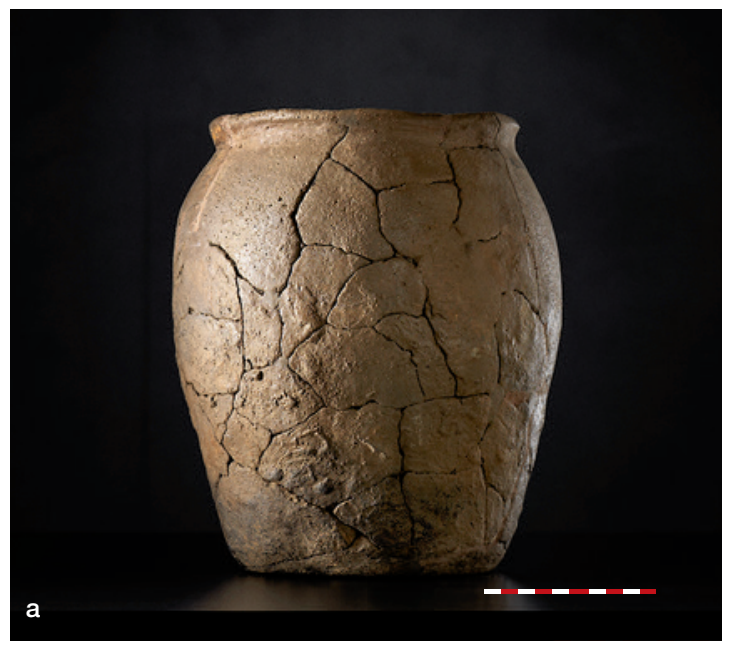

Fig. 5. Et udvalg af hele lerkar fra hus II. De stammer hovedsagelig fra området omkring lerbænken og den sydlige indgang. $5 \mathrm{f}$ er et stort firhanket lerkar, som ses direkte fra oven. - Foto: Martin Ravn Bendtsen, Fotoafdelingen, Moesgård.

A selection of entire pottery vessels from house II. These originate primarily from around the clay bench and the southern entrance. $5 f$ is a large vessel, seen directly from above.
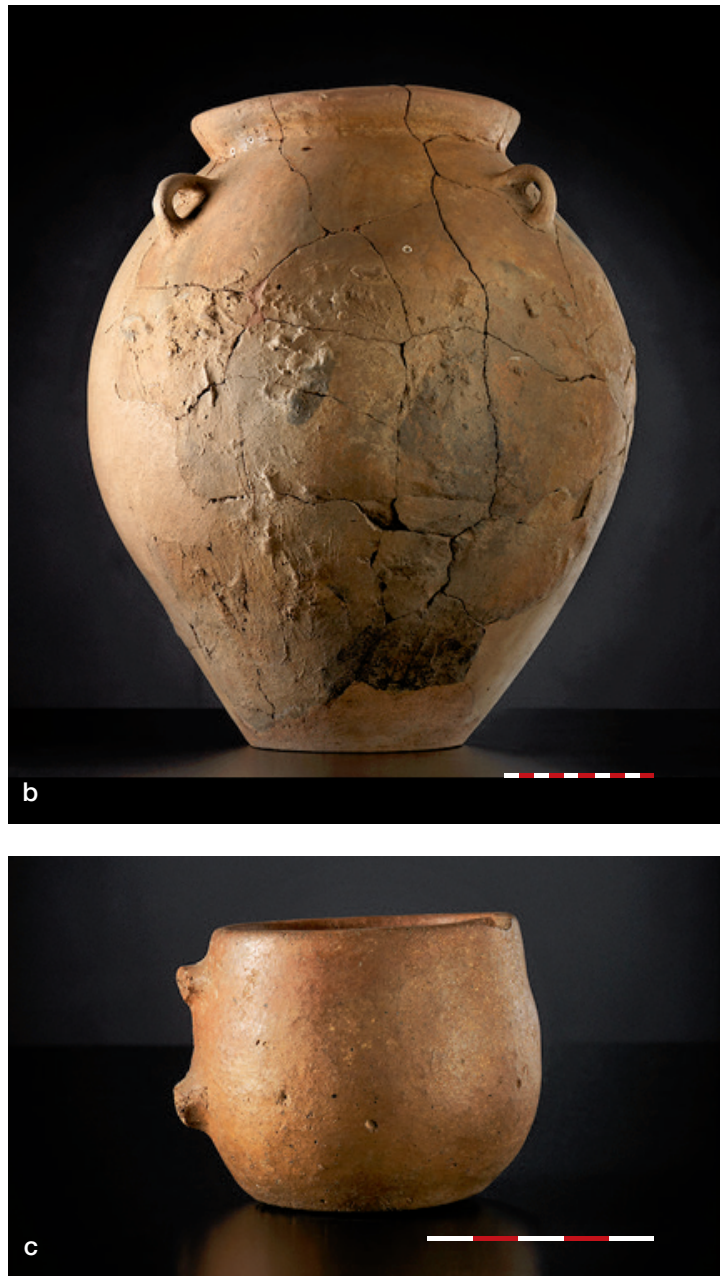

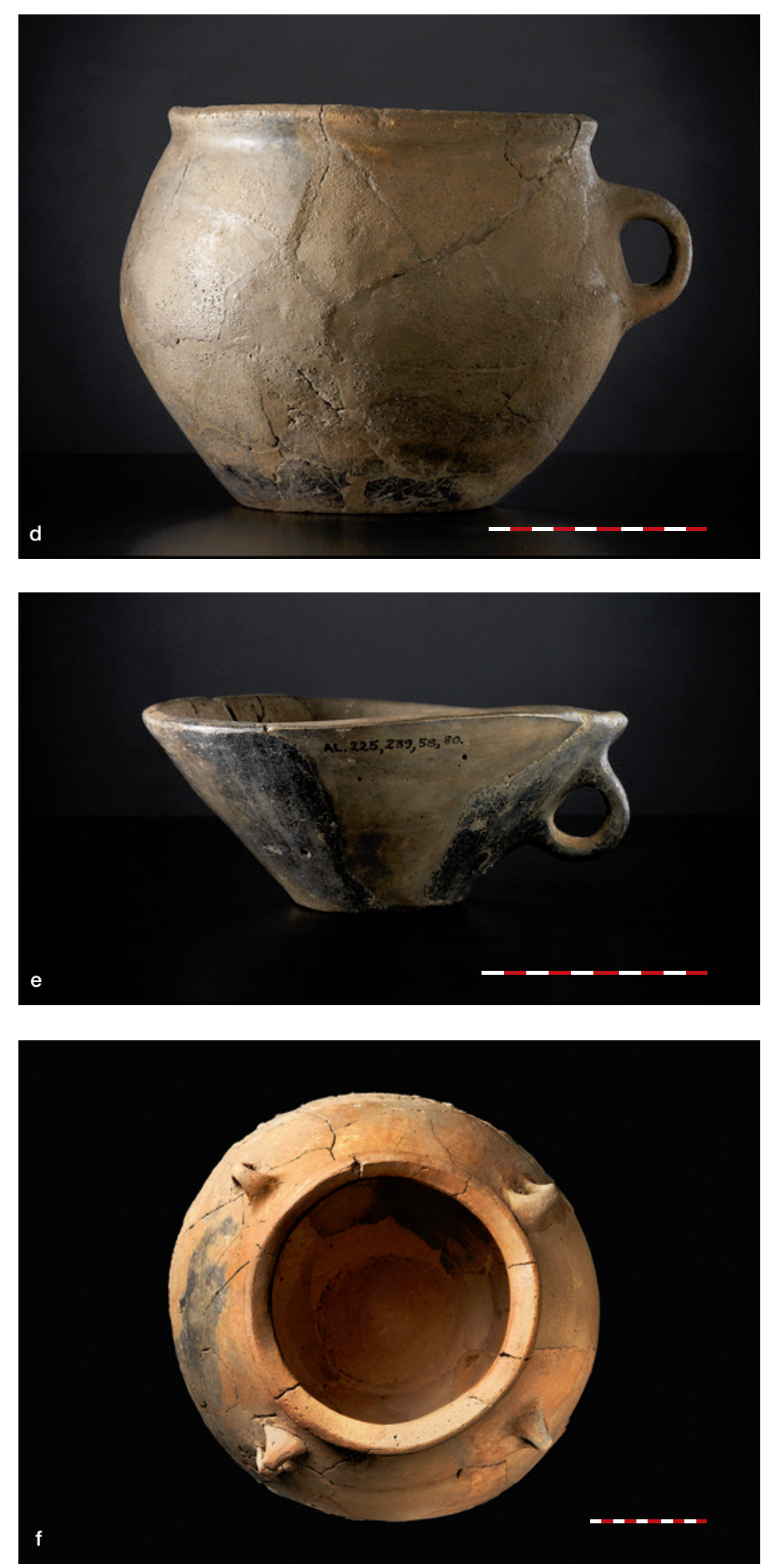


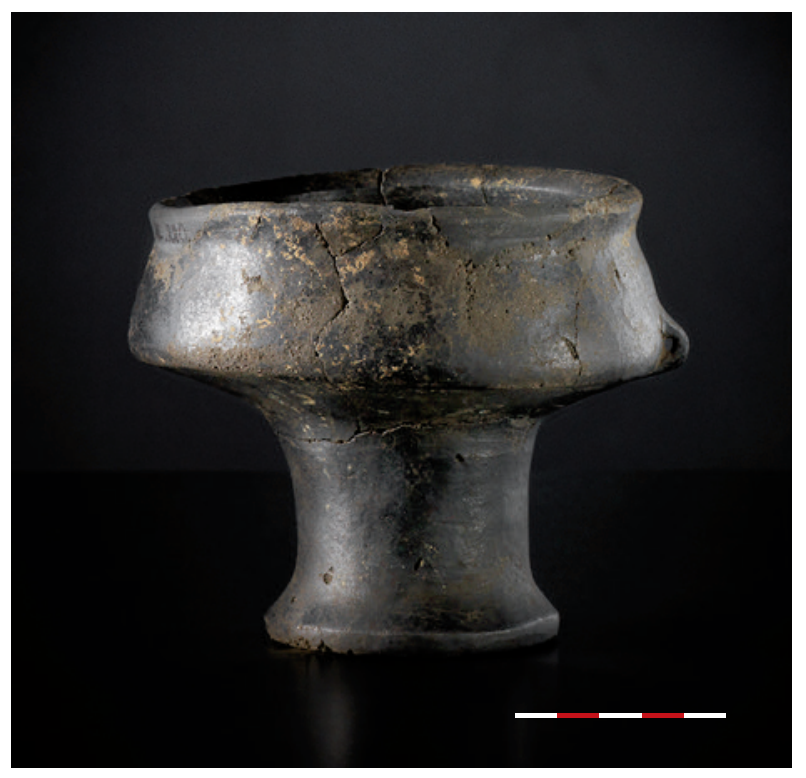

Fig. 6. Fodbæger fra hus II. - Foto: Martin Ravn Bendtsen, Fotoafdelingen, Moesgård.

Footed beaker from house II.

En del stykker har en lidt yngre karakter og må dateres til ældre romertid. Det drejer sig bl.a. om nogle få fodbægre (fig. 6) samt randskår med fortykket facetteret kant, og på flere af disse ses en fingerindtryksliste placeret direkte på randens yderside. Den samlede dateringsramme bliver derfor på 150-200 år. Men da hverken tag- eller vægstolper ser ud til at være udskiftet, kan huset kun have stået i en enkelt fase. Uanset længden af en sådan fase er dateringsrammen alt for bred, men forklaringen er formentlig, at der er sket indblanding i brandlaget fra yngre huse. Et eksempel herpå er en stor skåropsamling, hvorom det noteres, at denne er foretaget over hele udgravningen og oven over brandlaget. ${ }^{13}$ De mange skår repræsenterer 50-60 lerkar, og trækkes de fra det ovennævnte tal, ender man på omkring et halvt hundrede stykker fra selve brandtomten. Det svarer godt til, hvad der er fundet i andre velbevarede brandtomter. I Nr. Fjand er der registreret mindst 48 i hus IX, ${ }^{14}$ og i hus 3 i Gørding fandtes mere end 45 kar. $^{15}$

Det omfattende keramiske fundstof viser det sædvanlige sortiment af større forrådskar, store og mindre kar til daglig brug, skåle af forskellige former og størrelser, og desuden er der skår fra et par sikar og et ostekar samt fra diverse låg (fig. 7). Ildbukke findes naturligvis også, og særligt to store hornede og massive stykker gør indtryk (fig. 8). De var tydeligvis sat til side og lå som et par tæt op til nordvæggen og ud for ildstedet. De er $27,5 \mathrm{~cm}$ høje med en oval standflade på $18-20 \mathrm{~cm}$ og med en vægt på henholdsvis $3,2 \mathrm{og} 3,0 \mathrm{~kg}$. 
Fig. 7. Låg. - Foto: Martin Ravn Bendtsen, Fotoafdelingen, Moesgård.

Lid.

Fig. 8. De to store og massive ildbukke fra hus II, højden godt $27 \mathrm{~cm}$. Foto: Martin Ravn Bendtsen, Fotoafdelingen, Moesgård.

The two large solid andirons from house II, about $27 \mathrm{~cm}$ in height.
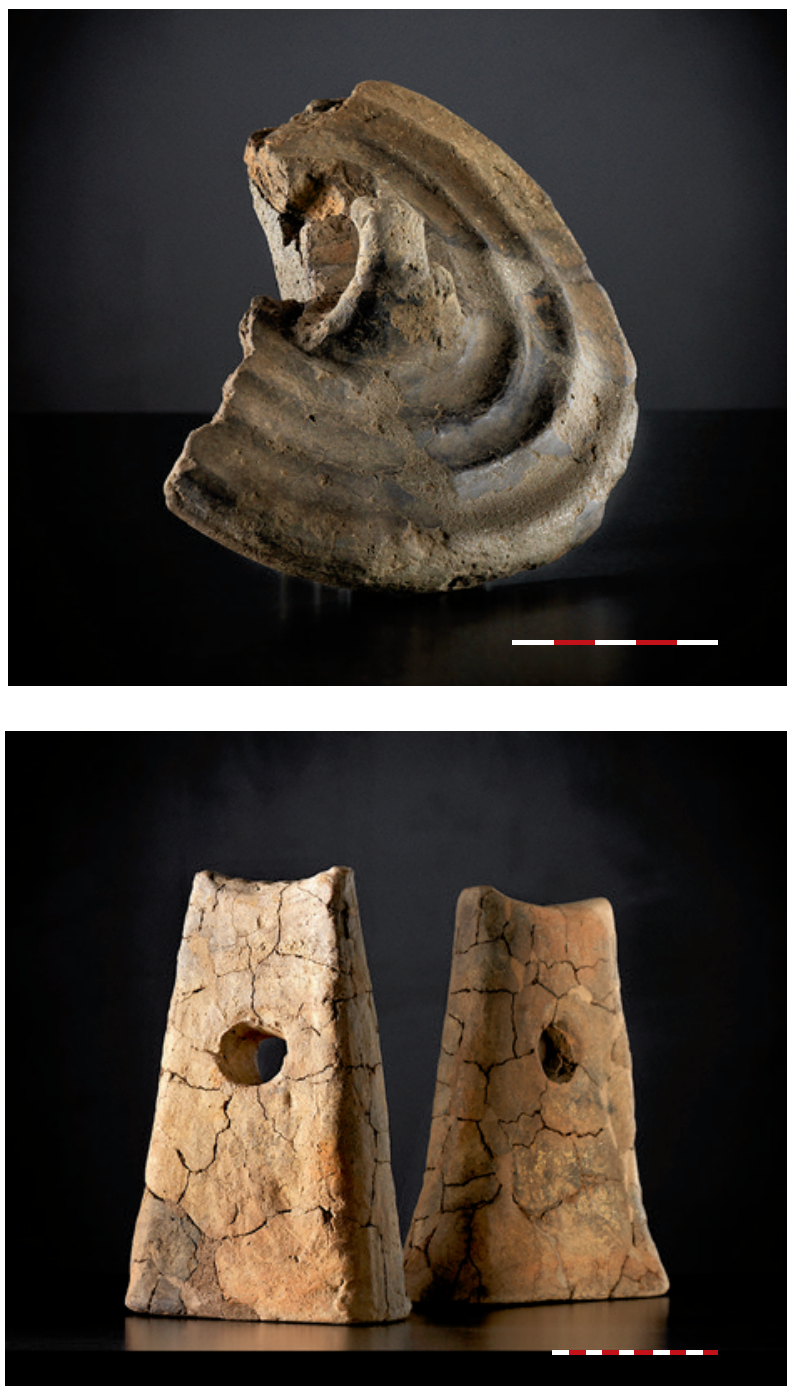

\section{Hus I}

Brandtomten lå umiddelbart under pløjelaget, og det var da også markarbejdet, som gav anledning til, at udgravningen kom i stand. Den var stærkt medtaget af moderne forstyrrelser, og kun husets midterste del omkring ildstedet var nogenlunde bevaret. I dette område lå adskillige lerkar, skår, trærester og diverse stenredskaber. Huset var orienteret vestnordvest-østsydøst og næppe mere end $11 \mathrm{~m}$ langt. Ved ildstedet var bygningen ca. 4,5 meter bred, og det antoges, at huset har haft lerklinede vægge ud fra et større stykke klining med aftryk af grenværk. De bedst bevarede dele var ildstederne og de forkullede tagstolper omkring dette. 
Det øverste ildsted var rektangulært med afrundede hjørner (1,55x1,25 m), og umiddelbart herunder lå endnu en arne af omtrent samme form og størrelse, så huset har formentlig haft to faser, men en anden mulighed er selvfølgelig, at ildstedet blot er blevet fornyet. Under kappen af det ældste ildsted fandtes en lille stenlægning med bl.a. syv knusesten og et lille lerkar, vel et offer, som det kendes fra et utal af jernalderhustomter. Omkring ildstedet stod fire forkullede dobbelte tagstolper af egetræ, og de fleste var spejlkløvede med enkelte kanthuggede imellem. Det er interessant, at de alle var placeret med de buede ydersider på tværs af husets længderetning; det styrker tagkonstruktionen og er et træk, der er typisk for husene på de nordvesttyske marskbebyggelser. Omtrent $10 \mathrm{~cm}$ under lergulvet sås mange stolpehuller fra ældre bygninger.

\section{Fundene}

Igen dominerer keramikken, og en gennemgang viser, at huset er fra ældre romersk jernalder, idet mange rande er fortykkede og facetterede (fig. 9). Et andet karakteristisk forhold er et større antal skår med ornamenter, bl.a. mæanderdekoration. På et enkelt skår består mønstringen af lette vandrette furer med en række pindstik. Desuden fandtes forskellige stenredskaber, bl.a. et par netsynk og en lille økselignende genstand af porfyr.

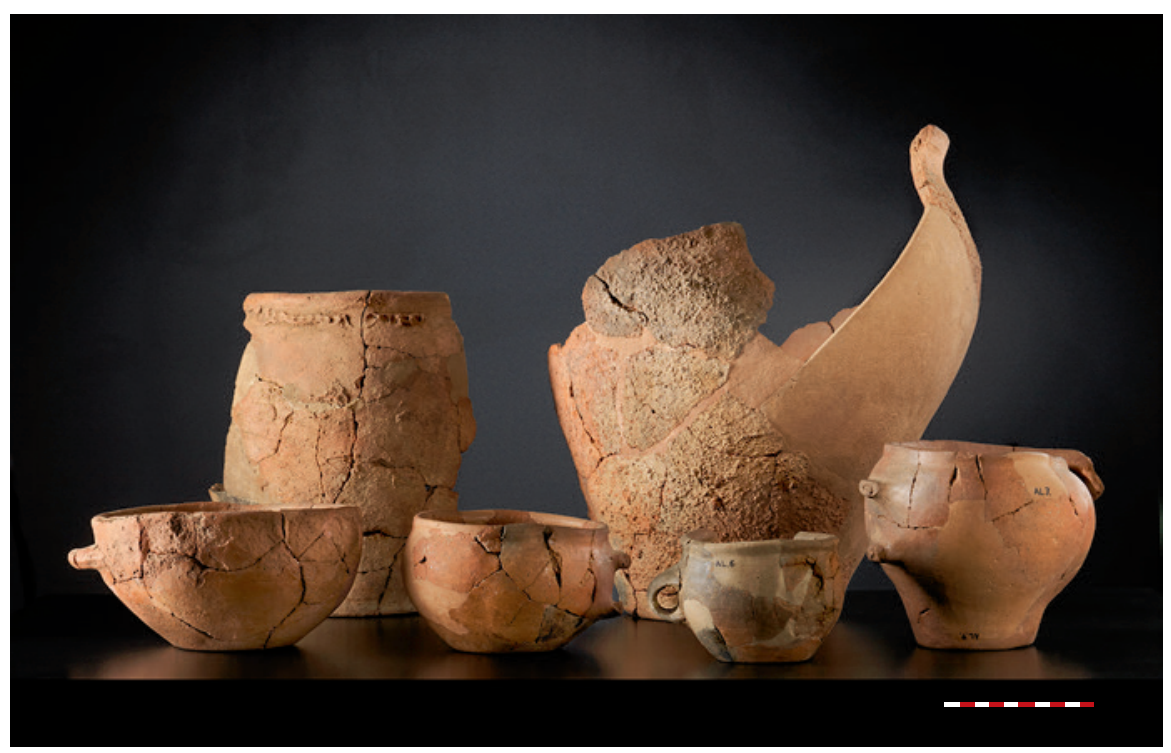

Fig. 9. Et udvalg af lerkar fra det lidt yngre hus I. - Foto: Martin Ravn Bendtsen, Fotoafdelingen, Moesgård.

A selection of pottery vessels from the slightly later house I. 


\section{Bygningskonstruktioner og forkullet tømmer}

De følgende betragtninger tager naturligvis udgangspunkt i de to brandtomter, med hus II som det vigtigste. Huset har som nævnt haft fem sæt tagbærende stolper, og i otte huller stod de forkullede rester tilbage. Der var dobbeltstolper i de fem af hullerne, og hensigten har givetvis været at gøre tagkonstruktionen så stærk som mulig, og ikke mindst fordi hver enkelt tagstolpe er forholdsvis spinkel. Måske er denne styrkelse af tagkonstruktionen et almindeligt regionalt træk, idet tilsvarende konstruktioner er kendt i både Nr. Fjand og Rødklit. Tagstolperne er husets stærke skelet, men vægkonstruktionen må også være solid. I Alrum er der relativt få forkullede vægstolper bevaret, og de måler 6-8 $3-4 \mathrm{~cm}$, hvilket jo ikke er meget, men lægges dertil det formodede svind og den korte systematiske afstand mellem stolperne, har man formentlig haft en solid væg. Som supplement kan nævnes, at de fleste vægstolpehuller i hus VIIA er kvadratiske med en side på $15-20 \mathrm{~cm}$, hvilket igen viser nødvendigheden af en kraftig væg.

I de to brandtomter stod usædvanligt meget af det indre egetømmer tilbage i form af forkullede stolpeender, som derfor kunne måles (fig. 10). Et væsentligt problem er imidlertid at bestemme svindet i forbindelse med en forkulning, så det bliver muligt at komme med et skøn over de oprindelige dimensioner.

Fra Dansk Brandteknologisk Institut oplyser man, at som tommelfingerregel regnes der med, at træ svinder 0,5-0,6 mm i løbet af et minuts brand.$^{16}$ Det næste spørgsmål er derfor, hvor længe et jernalderhus er om at brænde ned. På Historisk-Arkæologisk Forsøgscenter i Lejre er der en enkelt iagttagelse fra en kontrolleret brand, og her tog det ikke mere end 2-3 minutter, før taget kollapsede, og det vil sige, at stolperne allerede på dette tidspunkt skulle være svundet med ca. 1,0-1,2 mm. ${ }^{17}$ Men den totale nedbrænding tager selvfølgelig længere tid, hvorfor der må regnes med et større svind. Temperaturen spiller sandsynligvis også ind, og de forkrøblede lerkar samt afsprængte flager på flere stenredskaber antyder en temperatur på 1.000-1.100 grader. Lader man som et tankeeksperiment branden forløbe i 20 minutter, skulle der på bygningstømmeret og andet træ være afbrændt eller forsvundet ca. $1 \mathrm{~cm}$. Det lyder ikke af så meget, men ikke desto mindre øges styrken ganske væsentligt. Hvis en stolpe på $10 \times 10 \mathrm{~cm}$ får tillagt yderligere $1 \mathrm{~cm}$ på alle sider, bliver tværsnitsarealet næsten $25 \%$ større.

Men sammenlignes med de bevarede stolper i Feddersen Wierde og de få stykker fra Priorsløkke nær Horsens er der stadig en vis forskel. I Feddersen Wierde er alt det bærende bygningstømmer spejlkløvet af rette egestammer, og den radiære langside måler 25-30 cm, mens den krumme yderside er 15-20 $\mathrm{cm}$. I Priorsløkke er dimensionerne omtrent de samme. ${ }^{18}$ 


\begin{tabular}{|c|c|c|c|c|c|}
\hline \multicolumn{6}{|c|}{ Alrum Hus I } \\
\hline Nummer & Funktion & Længde & Bredde & Diameter & Tværsnit \\
\hline$x 16$ & Tagbærende stolpe & 18 & 8 & & 4 \\
\hline$\times 18$ & Tagbærende stolpe & 24 & 8 & & 口 \\
\hline$\times 19$ & Tagbærende stolpe & 15 & 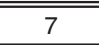 & & 4 \\
\hline$\times 20$ & Tagbærende stolpe & 13 & 7 & & 4 \\
\hline$\times 33$ & Tagbærende stolpe & 10 & 10 & & 4 \\
\hline$\times 34$ & Tagbærende stolpe & 5 & 5 & & 4 \\
\hline$\times 49$ & Tagbærende stolpe & 15 & 8 & & 4 \\
\hline$x 50$ & Tagbærende stolpe & 17 & 8 & & 4 \\
\hline \multicolumn{6}{|l|}{ Hus II } \\
\hline x 186 & Tagbærende stolpe & & & 17 & $\bullet$ \\
\hline$x 219$ & Tagbærende stolpe & 15 & 4 & & 口 \\
\hline x 196 & "Tagbærende stolpe & & & 16 & - \\
\hline x 197 & Tagbærende stolpe & 8 & 3,5 & & 口 \\
\hline$x 188$ & "Tagbærende stolpe & & & 15 & - \\
\hline$\times 189$ & Tagbærende stolpe & 7 & 7 & & ! \\
\hline x 195 & Tagbærende stolpe & & & 18 & - \\
\hline$x 195 \mathrm{~A}$ & Tagbærende stolpe & & & 10 & $\bullet$ \\
\hline x 192 & Tagbærende stolpe & & & 12 & - \\
\hline x 194 & Tagbærende stolpe? & & & 12 & $\bullet$ \\
\hline$x 230$ & Tagbærende stolpe? & 18 & 8 & & - \\
\hline \multicolumn{6}{|c|}{ Rødklit Hus A } \\
\hline$\times 19$ & Tagbærende stolpe & 8 & 6 & & $\square$ \\
\hline$x 24$ & Tagbærende stolpe & 15 & 7 & & 口 \\
\hline x 35 & Tagbærende stolpe & 13 & 10 & & 口 \\
\hline \multicolumn{6}{|l|}{ Hus C } \\
\hline$\times 5$ & Tagbærende stolpe & 15 & 12 & & 口 \\
\hline$\times 6$ & Tagbærende stolpe & 23 & 5 & & $\mathbf{\square}$ \\
\hline$\times 11$ & Tagbærende stolpe & 18 & 8 & & $\bar{\square}$ \\
\hline$\times 14$ & Tagbærende stolpe & 15 & 9 & & 口 \\
\hline$x 44$ & Tagbærende stolpe & 15 & 11 & & 口 \\
\hline x 45 & Tagbærende stolpe & 25 & 12 & & a \\
\hline \multicolumn{6}{|l|}{ Nr. Fjand } \\
\hline Hus lb & Tagbærende stolpe & 18 & 5 & & 口 \\
\hline Hus Ib & Tagbærende stolpe & 24 & 24 & & $\bullet$ \\
\hline Hus II & Tagbærende stolpe & 25 & 13 & & $\square$ \\
\hline Hus VII & Tagbærende stolpe & 25 & 9 & & $\square$ \\
\hline Hus IXc & Tagbærende stolpe & 28 & 8 & & 口 \\
\hline Hus IXc & Tagbærende stolpe & 28 & 9 & & 口 \\
\hline Hus XIV & Tagbærende stolpe & 12 & 8 & & घ \\
\hline Hus XIV & Tagbærende stolpe & 12 & 8 & & a \\
\hline Hus XVIII & Tagbærende stolpe & 15 & 6 & & - \\
\hline Hus XVIII & Tagbærende stolpe & 20 & 5 & & $\square$ \\
\hline
\end{tabular}

Fig. 10. Skema der viser dimensioner og tværsnit af det forkullede tømmer; suppleret med målinger fra Hatt 1953; Hatt 1957 og Webley 2008, s. 32, fig. 3.2. Stolpepar er angivet med dobbeltstreger. 


\section{Brandårsager}

I forbindelse med de mange nedbrændte jernalderhuse er det naturligvis nærliggende at diskutere årsagerne hertil. Skyldes det simpelt uheld, eller er afbrændingen forsætlig? I de tilfælde, hvor brandtomterne er så godt som fundtomme, må den mest oplagte mulighed være, at der er tale om en velovervejet handling, som har betydet, at husets inventar er blevet fjernet forinden. Grundene kan være mange. Huset kunne være gammelt og faldefærdigt, eller det kunne være "befængt med onde ånder". Ved andre fund er det derimod tydeligt, at årsagen har været en anden. Der kunne være tale om et rent uheld, men lige så sandsynligt er det, at branden kunne være forårsaget af udefra kommende fjender, idet man skal erindre sig, at vold og uro var et vilkår, som indgik i jernaldermenneskets tilværelse. I den slags situationer har huset selvfølgelig måttet forlades i største hast, og alt inventaret kan da blive liggende tilbage, som det ses i de to brandtomter.

\section{De ubrændte huse}

Bortset fra hus III i den nordøstlige del af feltet er resten beliggende under hus II, hvor der kunne udskilles en længere hussekvens. Under de nederste huse VIII og IX sås tilmed mange spor af ældre bygninger. De fleste tomter kunne kun udgraves delvist, med undtagelse af det lille hus VIIA (fig. 2).

Det er ildstederne og lergulvspartierne, som er de vigtigste lokaliseringsfaktorer, når hustomterne skal adskilles. De seks af husene var orienteret vestnordvest-østsydøst, mens VII, VIII og IX lå næsten vinkelret på de øvrige. Det er ikke ualmindeligt og kendes fra både Nr. Fjand og Rødklit. ${ }^{19}$

Hus V lå ganske få $\mathrm{cm}$ under hus II's vestende og delvist ind under sydvæggen. Det afdækkede lergulv målte ca. $6 \times 5 \mathrm{~m}$. Det rektangulære ildsted var temmelig ødelagt, men det havde været kantet med en dobbelt rammeornamentik. Under lerkappen lå en lille stenlægning, hvor stenene synes specielt udvalgte, idet de alle havde en ensartet størrelse som andexg. ${ }^{20}$ Umiddelbart herunder lå endnu et ildsted, som var ovalt, så igen er der formentlig tale om et hus i to faser. Omkring det øverste ildsted var der fire tagstolpehuller med en dybde på $50 \mathrm{~cm}$. Fundene var få, blot lidt keramik samt en kværnsten.

En smule under arnen $\mathrm{i}$ hus $\mathrm{V}$ lå et rektangulært ildsted tilhørende det lille hus VII, som var næsten kvadratisk med sidemål på 4,9x4,4 m, og med indgang i nordøstgavlen. Der lå en stenlægning med flere knusesten og skår under lerkappen. Som i det overliggende hus var der fire store tagstolpehuller omkring ildstedet, mens vægstolpehullerne på alle fire sider var forholdsvis små med en dybde på ca. $18 \mathrm{~cm}$, og en afstand mellem dem på 20-30 cm. 
Hullernes omrids antyder, at stolperne kan have været kanthuggede. Fundene er atter få, nogle skår og en kværnsten. Under dette hus lå endnu en bygning, hus VIIA, som var dårligt bevaret, og alene en del vægstolpehuller kunne iagttages; de fleste var firkantede og indrammede et vestnordvest-østsydøstorienteret hus på 5,5x3,5 m. Et flyvesandslag på 15 til $30 \mathrm{~cm}$ dækkede det delvist udgravede hus VIII, som udgjorde en del af denne hussekvens. Vægstolpehullerne stod med en afstand af $20-25 \mathrm{~cm}$ og var placeret i en op til 20 $\mathrm{cm}$ dyb væggrøft, men ellers var det småt med konstruktionsspor. Den udgravede del målte $6 \times 4,5 \mathrm{~m}$. Der blev opsamlet nogle skår og en tand fra kvæg, samt et spoleben fra får eller ged. ${ }^{21}$

Under den østlige ende af hus II og ca. $20 \mathrm{~cm}$ herunder blev der udgravet et parti af hus VI, som var tydeligt markeret af et forholdsvis velbevaret lergulv. Ildstedet var ovalt, og det lå direkte oven på et andet. Der var mange huller efter både tagstolper og vægstolper; de sidstnævnte var nærmest ovale, hvilket måske igen betyder, at vægstolperne har haft et rhombisk tværsnit. Nord- og sydvæggen var forlænget ca. 1 m mod vest, og da der ikke sås spor efter en væg, er udgravernes forslag i stedet, at der er tale om et åbent forrum. Lige så sandsynligt er det vel, at det er dele af et indgangsparti. Hvad angår relationen til de øvrige huse, antages huset at være samtidigt med hus V, som ligger omkring 6 $m$ derfra og med en grus-stenbelægning imellem. Der er fundet en del keramik, et lille netsynk, en kværnsten, en løber samt et lille stykke uforarbejdet rav, i øvrigt det eneste fra udgravningen.

Det sidste hus har nummer IX, og det lå yderligere $20 \mathrm{~cm}$ under hus VI og var orienteret nordnordøst-sydsydvest. Tomten var markeret af en væggrøft, og størrelsen kan derfor angives til ca. 6,3 x4 m. Midt i nord- og sydvæggen er grøften afbrudt af døråbninger. Som det var tilfældet ved hus VIII, sås i undergrunden mange stolpehuller og gruber både under huset og udenfor.

Hus III lå som det eneste delvist under hus I på et ca. $15-20 \mathrm{~cm}$ tykt gammelt dyrkningslag og omkring en meter under overfladen (fig. 2). Huset er registreret ud fra et lerlag, men ildstedet blev ikke påvist. Det var orienteret vestnordvest-sydsydøst med en mindste udstrækning på 9x3,5 m; antageligt har det haft en stald. Fundene var få, nogle skår samt en sænkesten.

\section{Stengenstande m.m. fra husene}

Der er fundet et mindre antal stenoldsager, og hyppigst optrædende er naturligvis dele af skubbekværne og de tilhørende løbere. Af andre genstande kan nævnes nogle hvæssesten, et par glittesten til brug ved pottemageriet, en ca. 20 $\mathrm{cm}$ lang slibesten med tre slibeflader intakt og seks netsynk, hver med en vægt på små $200 \mathrm{~g}$. Af mere utraditionelle sager fandtes en $14 \mathrm{~cm}$ lang økseformet 
Fig. 11. Forskellige stengenstande; a) viser seks små uregelmæssige netsynk, hvoraf et par er af flint. På b) ses i øverste række to glittesten og en hvæessesten, nederst en økseformet porfyrsten med en påbegyndt gennemboring i nakkeenden. - Foto: Martin Ravn Bendtsen, Fotoafdelingen, Moesgård.

Various stone artefacts: a) six small irregular net sinkers of which a couple are of flint. b) above, two burnishing stones and a whetstone; below, an axe-shaped porphyry stone with the beginnings of a perforation at the butt.

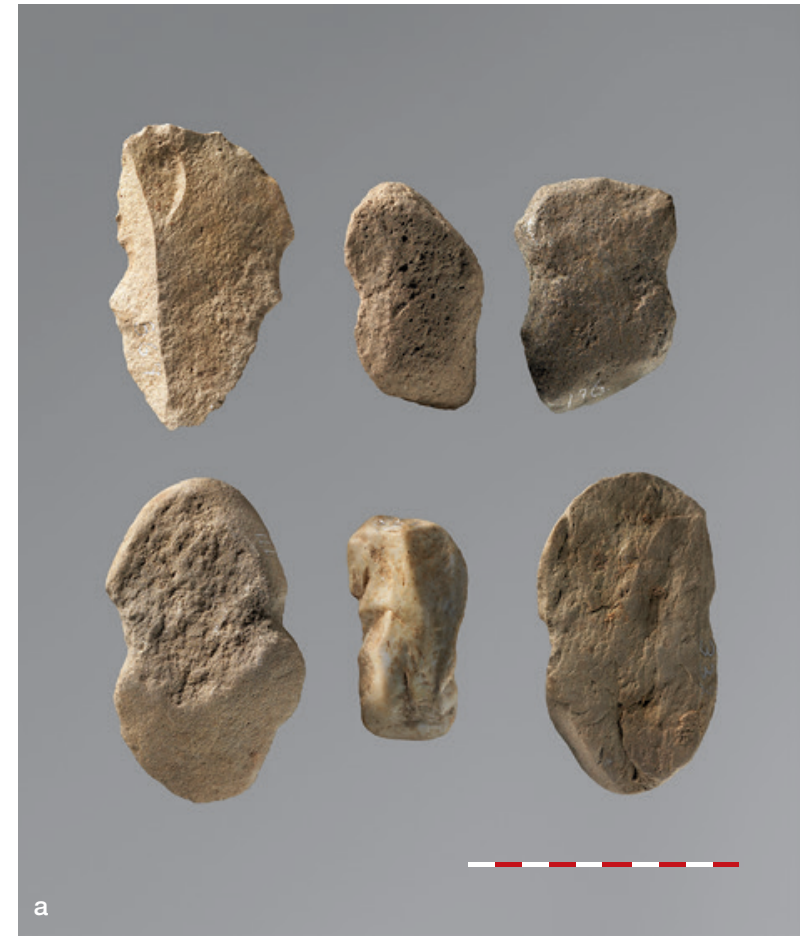

a
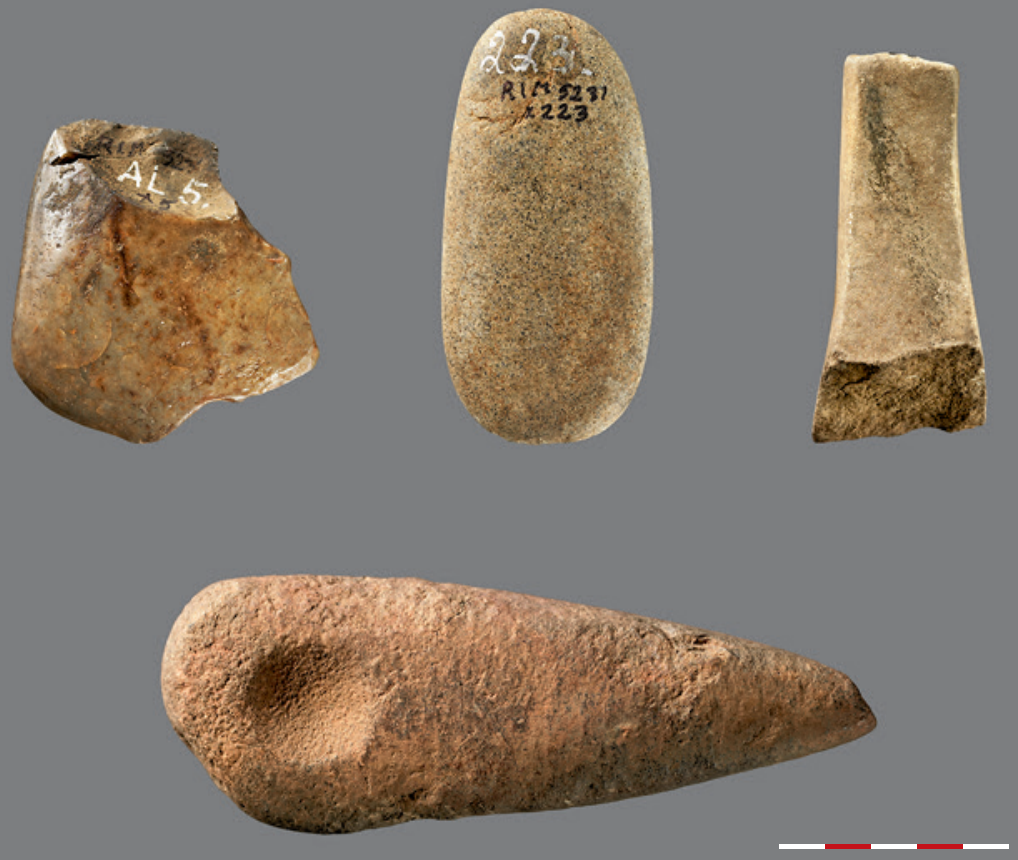

b 
sten af porfyr med påbegyndt gennemboring på nakkeendens over- og underside (fig. 11). Den stammer fra hus I, og det samme gør et dolkblad af flint. I hus II fandtes en enkelt gennemboret astragalknogle fra kvæg, og i hus VI det lille stykke uforarbejdede rav (fig. 12).

\section{Dateringen af de ubrændte huse}

Skårmængderne er ret små, men dog tilstrækkeligt til, at de i et par tilfælde giver et grundlag for en datering. Nederst i sekvensen ligger hus VIII, og her blev der opsamlet en del randskår, som alle er tynde og på et enkelt ses desuden en lav vulst på randens yderside. Nogle randstykker viser, at visse kar havde haft en relativ høj hals og dertil kom skår af båndformede hanke. Under huset var der spor efter endnu en bopladsfase med stolpehuller, gruber og en grøft; skår herfra er af samme karakter som i hus VIII. De nævnte træk er alle karakteristiske for den tidlige del af førromersk jernalder, hvilket vil sige, at bebyggelsen i Alrum må være etableret ca. 500 f.Kr. Det er heller ikke vanskeligt at datere de yngste hustomter til århundrederne omkring år 0 (fig. 13). Kildematerialet fra de mellemliggende huse er desværre mere mangelfuldt, men lagfølgen synes dog at vise en kontinuerlig bebyggelse gennem 500-600 år, hvilket
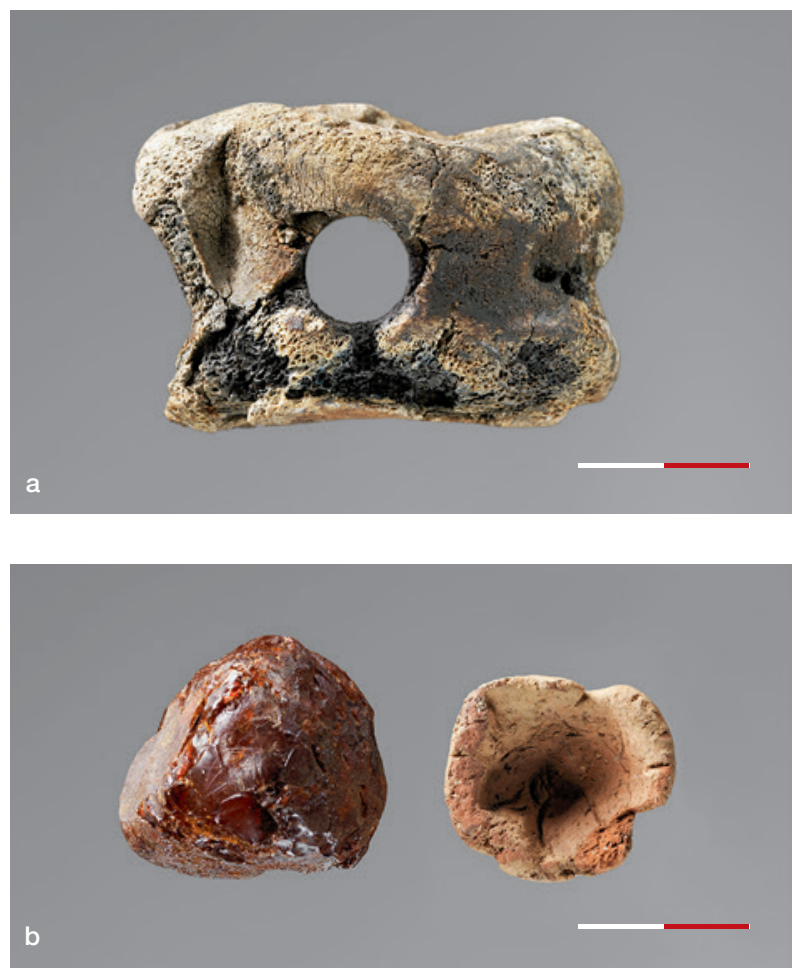

Fig. 12. a) viser en astragalknogle med gennemboring, måske til spil. b) er der til venstre en lille ravklump, og et miniaturelerkar på mindre end 2 $\mathrm{cm}$. Ravet er fra hus VI, mens de øvrige kommer fra hus II. - Foto: Martin Ravn Bendtsen, Fotoafdelingen, Moesgård.

a) astragalus with perforation, perhaps a gaming piece. b) left, a small piece of amber; right, a miniature pottery vessel of less than $2 \mathrm{~cm}$. The amber is from house VI, and the other pieces are from house II. 
desuden finder støtte i, at der ikke er konstateret vækstlag eller lignende mellem faserne.

\section{Bebyggelse og landskab}

Som tidligere nævnt er det ikke muligt at bedømme bopladsens størrelse eller husenes beliggenhed i forhold til hinanden, hertil er udgravningsfeltet for begrænset. Der er dog fundet både langhuse og mindst et lille ubrændt (hus V) på ca. $30 \mathrm{~m}^{2}$, men her drejer det sig formentlig om et mindre beboelseshus, idet det er forsynet med et rektangulært og dekoreret ildsted, som er omgærdet af fire usædvanligt dybe stolpehuller.

Næsten alle de totalt undersøgte huse på pladserne omkring Alrum er forholdsvis små. Hus II målte ca. 14,5x4,5 m, hvilket dermed passer godt ind i det store husmateriale fra Nr. Fjand. Fra den noget ældre boplads i Gørding var husene endnu mindre, idet de tre udgravede kun var ca. $10 \mathrm{~m}$ lange. Det er

Fig. 13. Sortglittet stejlvægget bæger med let udsvajet fod; fra hus VI. - Foto: Martin Ravn Bendtsen, Fotoafdelingen, Moesgård.

Black-burnished steepsided beaker with slightly flared foot, from house VI.

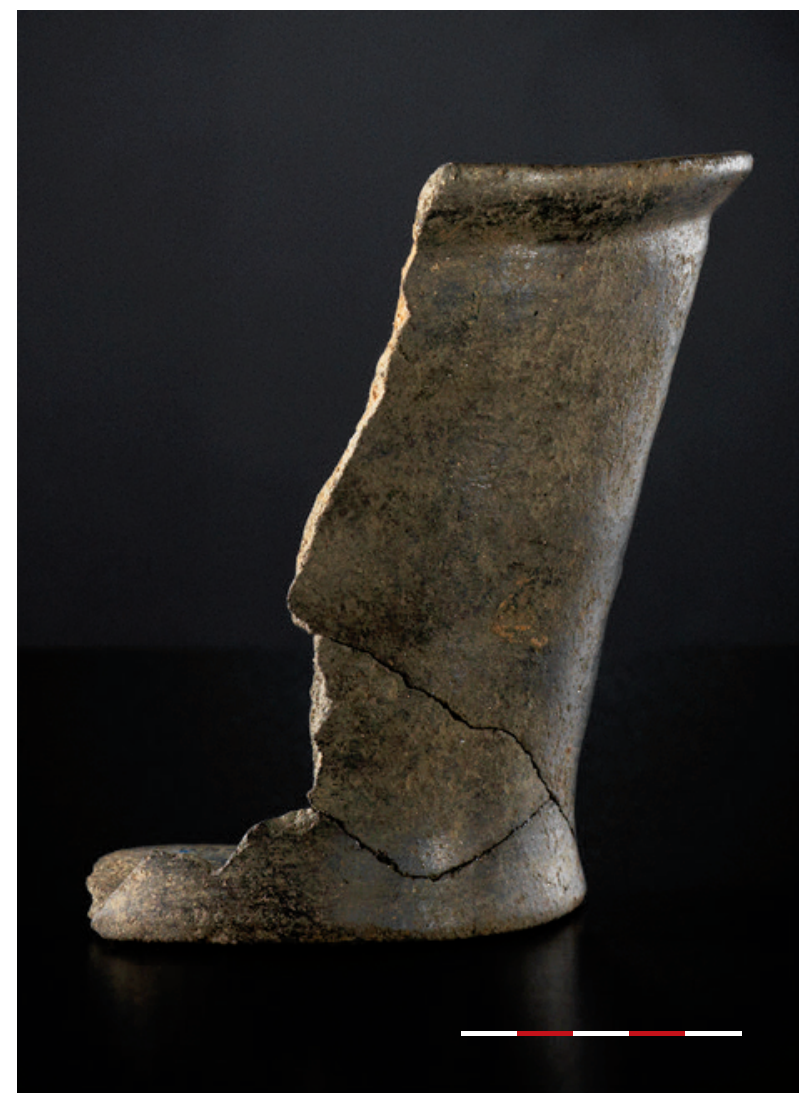


således tydeligt, at de vestjyske jernaldergårde har været mindre end i det øvrige Jylland. ${ }^{22}$ Om gårdene i Alrum har haft et mindre sidehus eller to, som det kendes fra mange andre af tidens landsbyer, er umuligt at afgøre. I Nr. Fjand er der imidlertid en del, som tyder på det; i hvert fald er der fundet mindst en 5-7 småhuse. ${ }^{23}$

Den ældre jernalders bebyggelser findes i stort tal i nærområderne ved Vesterhavet. I de fleste tilfælde har man bosat sig på lave højninger i landskabet med lettere jorder og nem adgang til vand. ${ }^{24}$ De her omtalte lokaliteter som f.eks. Nr. Fjand og Alrum ligger i dag nogle få kilometer fra kysten, men i jernalderen har kystlinjen været anderledes. Et tydeligt bevis på dette er, at der selv i den nuværende klitrække af og til dukker nye bopladsfund op, og det sker typisk i forbindelse med voldsomme storme. Den bedst kendte er Klegod på Holmslands Klit lidt nord for Hvide Sande, hvor såvel huse som dele af marker blev blæst fri i vinteren $1973 .{ }^{25}$ Den lille bebyggelse dateres til ca. 500 f.Kr., og der blev konstateret tre husfaser, så bosættelsen må have haft en vis varighed. Bopladsen er ikke den eneste på det strøg, så Holmslands Klit må have været dannet på dette tidspunkt, og Klegodfundet forudsætter endvidere, at datidens kystlinje har ligget længere vesterude, men det er uvist, hvor den gik.

I relation til bebyggelsen på Holmsland må også nævnes to quinarer fra Kejser Trajans tid (98-117 e.Kr.). Det er løsfund fra strandkanten ved Haurvig syd for Hvide Sande. ${ }^{26}$ Hvordan de er endt her kan kun blive rent gætteri. Måske stammer de fra et forlist romersk fartøj, der har sejlet langs kysten for at udforske landskabet, og som kunne være kommet fra den romerske flådes kvarter i Bentumersiel ved Emsflodens udløb? En anden og måske mere sandsynlig mulighed er, at de er skyllet $i$ land fra en nu forsvundet boplads. Et denarfund i et af husene på Ginderupbopladsen i Sydthy bør vel inddrages i denne sammenhæng. Her fandtes 24 denarer og en guldmønt i vægkonstruktionen, og med den yngste mønt slået i 74 e.Kr., og tankevækkende er det, at Ginderup heller ikke ligger så langt fra havet.

Selv om romerske importgenstande fra de første par århundreder efter vor tidsregning er yderst sjældne i det vestligste Jylland, er de to sølvmønter formentlig et godt udtryk for forbindelserne langs Nordsøkysten. Et enkelt fund kan supplere billedet, idet der i Hover sogn 8-10 km nordøst for Ringkøbing er fundet et meget sjældent romersk bronzefad, som er kantet med en æggestavsbort. ${ }^{27}$ Disse fă fund indikerer ikke desto mindre, at området højst sandsynlig indgik i den romerske interessesfære.

De mange bopladser burde også resultere i gravfund, men de er desværre fă, som det er tilfældet i det meste af landet. Heller ikke nær Alrum er der indtil videre fundet begravelser, og sandsynligvis er der tale om ganske små gårds- 
gravpladser liggende spredt i terrænet, hvorfor de er vanskelige at opspore. ${ }^{28} \mathrm{I}$ Nr. Fjand er der dog fundet en lille gravplads med 16 grave, som alle dateres til de første århundreder e.Kr. ${ }^{29}$ Men igen kan det undre, hvor de døde fra landsbyens øvrige faser ligger begravet.

\section{Landbrug}

Normalt giver bopladsudgravninger ikke mange oplysninger om levevilkårene eller livsbetingelserne, men det enorme fund af forkullede korn og frø i hus II hører stadig til blandt de bedste fra ældre jernalder i Danmark. I og med at udgravningen var yderst omhyggelig, giver det en unik mulighed for at få nærmere indblik i, hvordan vilkårene har været for indbyggerne i kyst- og fjordlandskabet i århundrederne omkring Kristi fødsel.

Afgrøderne har for en dels vedkommende været opbevaret i krukker, mens andet lå spredt på en sådan måde, at de mest sandsynligt har ligget på et stænge eller været ophængt i sække o.lign. (fig. 3). Flere steder var korn- og frølagene op til $10 \mathrm{~cm}$ tykke.

De første artsbestemmelser blev foretaget af Hans Helbæk under selve gravningen, men siden er makrofossilerne blevet analyseret igen (fig. 14) ${ }^{30} \mathrm{De}$ vigtigste kornsorter har været Byg og Havre, men også almindelig Hvede, hvis kerner dog er så små, at den nærmest må betegnes som Dværghvede. Hørplanter har man ligeledes kunnet se på de små ardfurede og sparsomt gødskede agre. Hørren er blandet op med frø fra bl.a. Rødknæ og Spergel, som er lave planter, og det betyder sandsynligvis, at den har været tilsvarende lav. På en god og velgødet mark bliver hørplanterne $1 \mathrm{~m}$ høje. De mange indsamlede smådynger af Spergel og Pileurt peger ligeledes i retning af, at markerne var sandede og kun småt gødskede. ${ }^{31}$ Flere dynger af de ukrudtsagtige arter var næsten rene, og de lå på en sådan måde, at de oprindeligt må have været opbevaret i lerkar. Både her og i mange andre brandtomter er det dokumenteret, at frøene fra først og fremmest Spergel, Gåsefod og Pileurt har været indsamlet. De er formentlig anvendt i både brød og grød, som det kendes fra nyere tid hos de jyske hedebønder. ${ }^{32}$ I den forbindelse er det ganske interessant, at også Draphavre er til stede, idet dens knolde er meget stivelsesholdige, og den er dermed ligeledes et godt kosttilskud. ${ }^{33}$

Analyserne viser, at der var både tærsket og utærsket korn til stede, og dertil meget hør. Blandingen af tærsket og utærsket korn kunne antyde, at branden er opstået engang i løbet af efteråret, hvor der stadig lå en del utærsket korn tilbage (fig. 15). Bestemmelserne viser, at man selvfølgelig også har praktiseret indsamling, idet både stenfrugt og kernefrugt er til stede. ${ }^{34}$ 


\begin{tabular}{|c|c|c|c|c|c|}
\hline \multicolumn{6}{|l|}{ Alrum } \\
\hline & \multicolumn{5}{|c|}{ Antal } \\
\hline & Prøvenr. 55 & Prøvenr. 78 & Prøvenr. 81 & Prøvenr. 112 & Prøvenr. 313 \\
\hline $\begin{array}{l}\text { Nøgen Seksradet } \\
\text { Byg }\end{array}$ & 3.545 & & 7.147 & & \\
\hline $\begin{array}{l}\text { Avnklædt Seksradet } \\
\text { Byg }\end{array}$ & 74 & & 99 & & \\
\hline Seksradet Byg & 1.363 & 3.508 & 1.776 & 46 & 51 \\
\hline Aksled Byg & 12 & & & 28 & 41 \\
\hline Alm. Hvede & 1.103 & 4.352 & 161 & 19 & 51 \\
\hline Havre & & & & 4.736 & 7.329 \\
\hline Havre sp. & 6 & 32 & 12 & & \\
\hline Ubestemt korn & & & & 456 & 245 \\
\hline Knoldet Draphavre & & & & 3 & \\
\hline
\end{tabular}

\begin{tabular}{|l|r|r|r|}
\hline \multirow{2}{*}{} & \multicolumn{3}{|c|}{ Antal } \\
\cline { 2 - 4 } & Prøvenr. 314 & Prøvenr. 77 & Prøvenr. 72 \\
\hline Vej-Pileurt & & 7 & \\
\hline Snerle-Pileurt & 8 & & \\
\hline Fersken/Bleg Pileurt & 1.310 & 5.938 & 1.736 \\
\hline Pileurt sp. & 16 & & \\
\hline Potentil sp. & & 14 & \\
\hline Rødknæ & 119 & 977 & 87 \\
\hline Kogleaks sp. & & & 27 \\
\hline Enårig Knavel & & 7 & 25.833 \\
\hline Spergel & 28.336 & 200.000 & 40 \\
\hline Alm. Fuglegræs & 8 & 145 & 7 \\
\hline Viol sp. & 8 & 7 & 47 \\
\hline Ubestemt frø & 24 & 10 & + \\
\hline $\begin{array}{l}\text { Stængelstykker, } \\
\text { Rodbaser, halm }\end{array}$ & + & + & \\
\hline
\end{tabular}

Fig. 14. Uddrag af artslisten over korn og frø fra hus II. - Efter Henriksen og Robinson 1994, bilag 17-18.

Derimod er der ikke meget at hente i de ganske få og stærkt forbrændte dyreknogler, som blot dokumenterer tilstedeværelsen af kvæg og får eller ged..$^{35}$ I øvrigt er mange af de udgravede stalde i området ganske små med plads til blot nogle få dyr, og størst er indtil videre en stald i Nr. Fjand med 17 båse. Mulighederne for god græsning synes ellers at have været til stede på strandengene, som er meget næringsrige og udgør udmærkede arealer for både græsning, høslet og dyrkning. Der er tilmed den fordel, at de ligefrem har godt af at blive oversvømmet engang imellem. Flere planter som Byg, Hør, Sæd-dodder og Hestebønne tåler nemlig lidt salt. Endnu en faktor må nævnes, nemlig grundvandsspejlet, som jævnligt ligger højt på de lettere jorder, hvilket betyder, at de sjældent tørrer helt ud. ${ }^{36}$

Det generelle indtryk, som med forsigtighed kan udledes af nedennævnte pollenanalyser fra Bos Sø, er, at landskabet har været relativt åbent, men med 


\begin{tabular}{|l|c|c|l|l|l|l|}
\hline Nummer & Vægt & $\begin{array}{l}\text { Tærsket og } \\
\text { renset }\end{array}$ & Utærsket & Art & $\%$ & Andet \\
\hline x 55 & $2.081 \mathrm{~g}$ & $\mathrm{x}$ & & Byg & 71 & Spergel \\
\hline $\mathrm{x} 78$ & $430 \mathrm{~g}$ & $\mathrm{x}$ & & Byg & & \\
\hline $\mathrm{x} 81$ & $5.567 \mathrm{~g}$ & $\mathrm{x}$ & & Byg & 96 & \\
\hline $\mathrm{x} 112$ & $1.034 \mathrm{~g}$ & $\mathrm{x}$ & & Havre & 96 & Draphavre \\
\hline $\mathrm{x} 72,77 \& 314$ & $3.768 \mathrm{~g}$ & $\mathrm{x}$ & $\mathrm{x}$ & Byg & & Spergel \\
\hline
\end{tabular}

Fig. 15. Skema der viser tærsket og utærsket korn fra hus II. - Efter Henriksen og Robinson 1994.

gode muligheder for græsning på både lyng- og græsarealer. Lynghederne er givetvis blevet vedligeholdt ved høstning, afbrænding m.v., og de har sikkert spillet en væsentlig rolle som vintergræsningsarealer, og den lune Golfstrøm bevirker endvidere, at perioden for udegræsning på engene har kunnet forlænges med et par måneder.

\section{Fiskeri}

I og med at mange af bopladserne ligger tæt ved både vandløb og fjorde, ville man forvente flere spor efter fiskeri, men i den sandede jord opløses fiskeknoglerne desværre hurtigt, og kun i Nr. Fjand er fundet nogle få. Men netsænkestenene viser med sikkerhed, at man har drevet netfiskeri. I Alrum blev der dog kun fundet seks stykker fordelt på fire tomter. De var alle små og med en gennemsnitsvægt på under $200 \mathrm{~g}$. Der var tale om almindelige marksten og et par flintstykker med en kun svagt markeret fastbindingsfure. De tilhører gruppe I, som er små med længder på $6-9 \mathrm{~cm} \cdot{ }^{37}$ Smådynger af netsynk, som det kendes fra Nr. Fjand og Rødklit, var fraværende, men de kan sagtens ligge i de tomter, som lå uden for udgravningsfeltet. Ved den begrænsede udgravning af Rødklit fandtes således ikke mindre end 28 netsynk og heraf en enkelt samling med otte sten. ${ }^{38} \mathrm{Ud}$ fra såvel bopladsernes beliggenhed som fundmaterialet er det berettiget at betegne beboerne som fiskerbønder.

\section{Skovbilledet}

Udgravningsfeltet i Alrum var efter moderne forhold temmelig begrænset, men ikke desto mindre er det en undersøgelse, som giver anledning til overvejelser om bl.a. skovbilledet, kystforløbet og ikke mindst sandflugtens omfang og betydning.

Egetræet er her som alle andre steder absolut dominerende i byggeriet, men der anvendes dog også andre træarter med pil og el som de almindeligste. De 
er velegnede til forskellige former for fletning, og de findes da også især som tynde pinde eller kviste med bark, der i mange tilfælde er fulde af billegnav. Bøg og ask er blot registreret i få tilfælde, men mere interessant er vel tilstedeværelsen af stenfrugt (Prunus) og kernefrugt (Pomoideae). ${ }^{39}$

Den udbredte brug af egetræe er umiddelbart overraskende i Jyllands vestligste dele, og ikke nok med det. Egetømmeret er i betydeligt omfang blevet tilhugget, og det er en bearbejdningsmåde, som ikke just tyder på, at det var vanskeligt at få fat i egetræ.

Med Ulfborgprojektets fornemme udgivelse "Mellem Hav og Hede" får man serveret de nyeste resultater af såvel naturvidenskabelige som kulturhistoriske undersøgelser. ${ }^{40} \mathrm{Med}$ hensyn til vegetationen er det først og fremmest pollenanalyser, som kan belyse skovforholdene. Det nærmeste pollendiagram er ovennævnte fra Bos Sø, der ligger ca. 4 km syd for Ulfborg og ikke så langt fra Nissum Fjord, hvor Nr. Fjand er beliggende. Afstanden til Alrum er imidlertid blot 4-5 km, hvorfor det antages, at resultaterne er nogenlunde retvisende for landskabsforholdene omkring Alrum. ${ }^{41}$

Tilbagegangen for de vestjyske skove sætter tidligt ind, og omkring Kristi fødsel karakteriseres landskabet som et "meget nøgent landskab", og det forklares med, at denne tilbagegang for skoven skyldes et øget behov for græsarealer. ${ }^{42}$ Det fremgår af diagrammet, at eg har været til stede, men næppe som større skove, hvorfor tanken om, at det nødvendige tømmer kunne være "importeret” fra Østjylland, forekommer nærliggende. Det ville i så fald minde om forholdene på de nordvesttyske og hollandske marskbopladser, hvor der ikke er tvivl om, at de mange og store egestammer er kvalitetstræ tilført fra fastlandet, måske til gengæld for græsning på marskengene. En eventuel tilførsel af egetræ fra det østjyske område kunne da eventuelt være udvekslet med saltede og røgede fisk? En anden mulighed kunne være salt, hvilket Gudmund Hatt allerede overvejede i forbindelse med udgravningen i Nr. Fjand.

\section{Vestkystlandskabet}

Et andet interessant spørgsmål vedrører kystlinjens forløb gennem tiderne, men en ting står klart med bebyggelsesfundene lige i kanten af klitterne, at kysten må have ligget et godt stykke længere mod vest. Men eftersom det geologisk og geografisk er et meget dynamisk område, er det uhyre vanskeligt at komme med et realistisk bud. Det skyldes selvfølgelig, at de arealer, som kunne studeres, for længst er forsvundet i Vesterhavet.

For Thys vedkommende er der dog gjort forsøg på at estimere, hvor meget land, der kan være opslugt af havet. Udgangspunktet er Videnskabernes Sel- 
skabs Kort fra 1790'erne, og her kan man direkte måle, at kysten siden dengang har forskudt sig mod øst. Et overordnet skøn lyder på, at kysten har rykket sig en 2-3 km for hvert årtusinde, hvilket vil sige, at den omkring år 0 kan have ligget 5-6 km længere mod vest end i dag! $!^{43}$

En anden faktor er havspejlets variation over tid. ${ }^{44} \mathrm{Et}$ par gode eksempler på kystområdets dynamik ses eksempelvis ved den tidlig førromerske boplads, Klegod, som blev fundet direkte i kanten af klitten og på romertidsbebyggelsen Højbjerg i Sdr. Bork Mærsk lige syd for Ringkøbing Fjord. Sidstnævnte ligger på en lille højning, og i flere profilsnit ses sandaflejringer, men mest interessant er et klæglag, som ligger henover bopladsen. Klæglaget viser, at havspejlet på et tidspunkt efter 2. århundrede e.Kr. må have været højere, så klægen har kunnet afsættes i forbindelse med tidevandets skiften. I lagene lige over bopladsen er der da også fundet både saltvandsdiatomeer, og andre arter, som kan leve i både fersk- og brakvand. Stratigrafien i Højbjerg er ikke enestående, idet den kendes fra mindst to andre lokaliteter, Velling og Stavning ved fjordens østkyst, fig. 1. ${ }^{45}$

Havspejlsvariationerne og de mulige hævninger og sænkninger på det faste land må selvfølgelig have haft indvirkning på de mange bebyggelser, som fin-

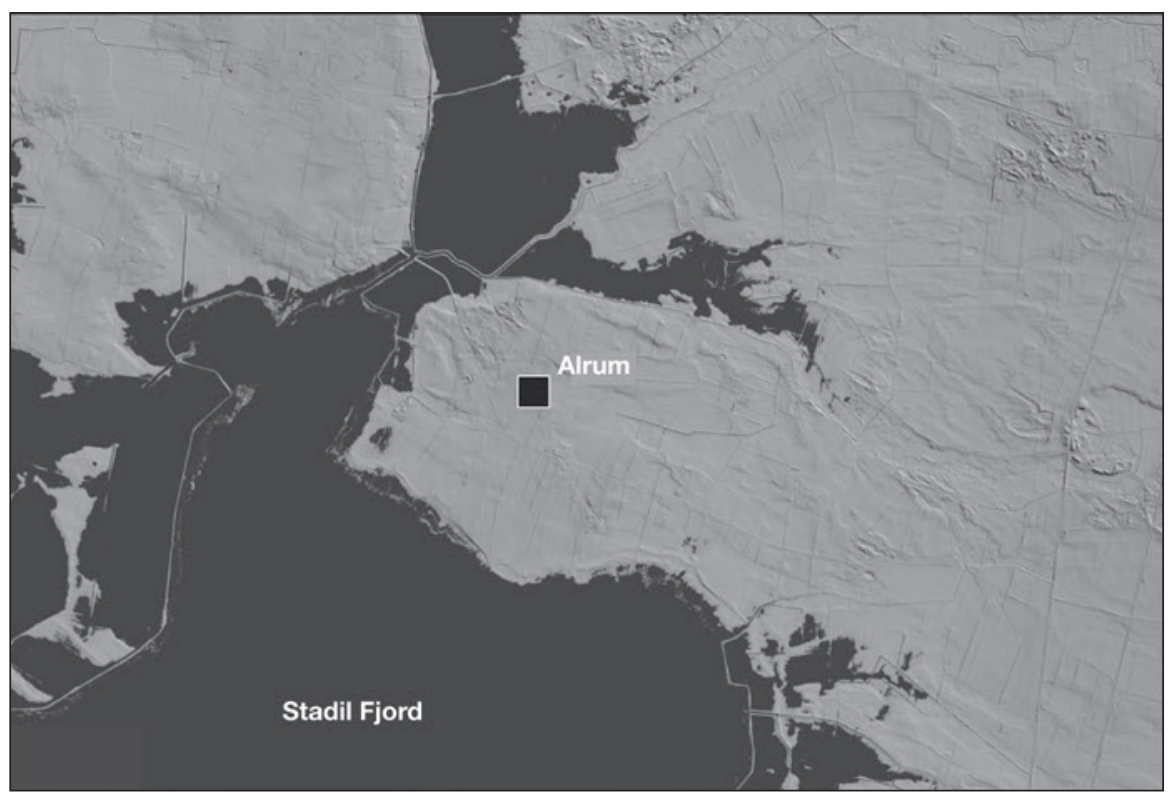

Fig. 16. Kort over området med angivelse af forholdene, hvis det antages, at vandspejlet $\mathrm{i}$ perioder har ligget 0,5 m højere. - Tegning: Poul Nissen.

Fig. 16. Map of the area showing the conditions prevailing with a $0.5 \mathrm{~m}$ increase in sea level during the period. 
des i området. Om det har haft betydning for dagliglivet i Alrum er vanskeligt at afgøre, men blot en mindre stigning i havniveauet får som konsekvens, at landsbyen kommer til at ligge noget nærmere bredden af Stadil Fjord og med en tilsvarende indskrænkning af strandengene (fig. 16). En anden effekt af variationerne er naturligvis, at en bredere forstrand i perioder øger muligheden for en større sandflugt. ${ }^{46}$

\section{Sandflugtens omfang og indvirkning}

I dag har de fleste en opfattelse af, at den jyske vestkyst er karakteriseret af klitter med dertil hørende sandflugt, men sådan kan det ikke altid have været, hvilket tydeligt fremgår af fundene. At det har været muligt at bo i disse egne må bero på, at klimaet har været mindre barskt, og at man trods alt har kunnet leve med en vis sandflugt, som det er konstateret ved udgravninger i Klegod, Alrum, Nr. Fjand og Rødklit. Bopladserne er tit anlagt på gamle markflader, hvilket viser, at der må have eksisteret endnu ældre bebyggelser i nærheden. Det tyder på, at sandflugten i ældre jernalder har haft et langt mindre omfang end senere. Mange bopladser ser imidlertid ud til at være dækket af flyvesand og forladt i ældre romersk jernalder, så måske har havspejlet samt vind- og strømforholdene været i færd med at ændre sig allerede på dette tidspunkt. De meget store klitformationer, som vi kender dem i dag, menes dog at være et relativt sent fænomen.

På mange af disse fjord- og kystnære bebyggelser ses naturligvis fygesandslag over såvel marker som imellem husfaserne. Men betydningen og omfanget af sandflugten har sjældent været diskuteret, og spørgsmålet er derfor, om sandet overhovedet har haft den store indflydelse på bøndernes liv og levned?

Udgravningen i Alrum giver imidlertid værdifulde oplysninger og en bedre indsigt i forholdene. I sekvensen under hus II lå hus VII på et 15-30 cm tykt lag sand, som igen dækkede det underliggende hus VIII, der var bygget på et sandlag af 12-16 cm's tykkelse, og heri sås yderligere kulturspor. Selv om sandlagenes tykkelse kan forekomme voldsomme, er det dog ikke mere, end hvad der kan aflejres i løbet af ganske kort tid, måske bare over natten, og det forhindrer da heller ikke, at man har boet mange generationer på et og samme sted. I Alrum drejer det sig vel omkring et halvt årtusinde. Det har åbenbart været mere besværligt at flytte end at blive boende med engene og de små marker lige i nærheden.

På bopladsen Klegod på Holmsland Klit ses ligeledes sandflugtslag både i og under bebyggelsen, der omfatter mindst tre faser. De samtidige marker i Kle- 
god er blevet dækket af fygesand i flere omgange, men dog ikke mere end det har været muligt at pløje eller ærje igennem et sandmuldslag på hele $40 \mathrm{~cm}$, så den underliggende muld er kommet med op i dyrkningslaget. ${ }^{47}$ I Nr. Fjand er der ligeledes adskillige eksempler på, at man har levet med fygesandet. Der er sand både mellem husgulvene og på de omgivende marker. Et par gode eksempler ses ved husene XXb og Vg, som er opført på et ca. $20 \mathrm{~cm}$ tykt fygesandslag, hvorunder der ligger en 25-50 cm tyk zone af sandmuld med enkelte skår og mindre sten samt ardspor, der når ned i det underliggende sandflugtslag. ${ }^{48} \mathrm{I}$ Rødklit sås også mange aktiviteter under de huse og ildsteder, som Hatt undersøgte i $1946 .{ }^{49}$ Under hus A og i ca. 60 cm's dybde blev der således afdækket marker, hvilket igen er et eksempel på en boplads anlagt på en ældre markflade.

Den overordnede konklusion må derfor være, at sandflugten i ældre jernalder i perioden $500 \mathrm{f.Kr}$. til ca. $150 \mathrm{e} . \mathrm{Kr}$. ikke ser ud til at have haft et omfang, som har tvunget beboerne til at forlade landsbyen. Til gengæld synes stort set alle bebyggelser at opgives og markerne lægges øde engang i løbet af det 2 . århundrede e.Kr. Om dette i virkeligheden er et tegn på, at sandflugten intensiveres på dette tidspunkt, er stadig uklart, men påfaldende er det i hvert fald, at de omtalte bebyggelser synes at være forseglede under tykkere flyvesandslag.

\section{Afsluttende bemærkninger}

Udgravningsarealet i Alrum er som nævnt beskedent, men ikke desto mindre har undersøgelsen givet anledning til forskellige betragtninger over bebyggelsesforholdene og livsbetingelserne i denne kystzone.

Et centralt spørgsmål er selvfølgelig, hvorfor man allerede så tidligt som omkring år 500 før Kristi fødsel begynder at flytte ud i disse, set med vore øjne så lidet gæstmilde omgivelser, og hvordan det har kunnet ladet sig gøre at leve og ikke mindst overleve her? Udgravninger viser med sikkerhed, at det har kunnet ladet sig gøre, og at der ikke bare er tale som kortvarige besøg i forbindelse med f.eks. sæsonfiskeri. Mange af landsbyerne har eksisteret gennem adskillige århundreder, og frem mod år 0 øges antallet af bosættelser tilmed voldsomt.

Hvad kan de mulige årsager være til, at mennesker slår sig ned i dette område? Et befolkningsoverskud kan formentlig afvises, idet der næppe har været mangel på land ved overgangen bronzealder/jernalder. I stedet kunne det være særlige grupper af befolkningen, småkårsfolk, som har måttet tage til takke med disse vilkår. Det er en mulighed, da både landsbyerne og husene er små, men uanset bevæggrundene holdes traditionerne i hævd: med beboelse i vest og stald i østenden, ornamenterede ildsteder, lerbænke ved vestgavlen m.m. 
De mange erhvervsmæssige muligheder må naturligvis ikke undervurderes. Adgangen til hav og fjord er selvfølgelig blevet udnyttet til fiskeri. De gode og næringsrige strandenge ligger nær bebyggelserne, men staldene er generelt meget små. Det tyder ikke direkte på, at det var kvæg, man især lod græsse på engene, men vore forestillinger om staldenes funktion er i det hele taget problematisk. Har de blot været brugt til ammedyrene, eller har man i vinterperioden kunnet se en stald for sig med de forskellige husdyr? Et af de senere års mest spektakulære fund peger i den retning, idet der i en nedbrændt stald fra Nørre Tranders nær Ålborg blev fundet knogler af et par heste, adskillige stykker kvæg samt af făr, grise og en hundehvalp. ${ }^{50}$

I Alrum er det måske fåreholdet, som har spillet den væsentligste rolle, men desværre er det samlede knoglemateriale for småt til at afgøre det. På den kystnære byhøj Smedegård i Thy er knoglematerialet derimod meget stort, og her er der ingen tvivl om, at det er fåreavl, som udgør det økonomiske grundlag i kombination med de marine ressourcer. ${ }^{51}$

Den stedbundne og langvarige bosættelse, som ses både i Alrum, Nr. Fjand og Klegod, er selvfølgelig tankevækkende med op til ca. 500 års ophold på samme sted, som det ser ud til at være tilfældet i Alrum. I Nr. Fjand eksisterer den store landsby i mindst 300 år, og i Klegod er der konstateret tre huse over hinanden. I Alrum dannes der et kulturlag på ca. 1,5 m, og derfor er det berettiget at kalde den for en byhøj. Det samme gør sig gældende for Nr. Fjands vedkommende. Disse stedbundne bopladser er velkendte fænomener både i Thy og på de nordvesttyske og hollandske marskbosættelser.

Det forhold, at husene er beliggende omtrent lige over hinanden, antyder en stærk tilknytning til et bestemt areal, en "parcel" i landsbyen, og det er blevet foreslået,,$^{52}$ at det kunne være et udtryk for familiemæssige relationer mellem beboerne i de enkelte gårde.

\section{NOTER}

1. Alrum. Stadil s., Hind h., Ringkøbing a., sb.16. Ringkøbing Museum j.nr. 5231; NM: Top. Ark. 381/38. Oldsagerne er indgået til Ringkøbing Museum omkring 1960, mens beretningen først dukkede op i 2000. På Ringkøbing er fundene mærket med $\mathrm{AL}+$ fortløbende tal i relation til beretningen. I forbindelse med denne artikel er alt materialet blevet omnummereret med museets j.nr. + fortløbende tal (ex. 5231x48). Vi vil gerne takke museumsinspektør Palle Eriksen for tilladelse til at publicere fundet.

2. Citeret efter Henriksen og Robinson 1994, s. 21.

3. Beretningsteksten oplyser, at der er taget 81 fotos. De er forsøgt opsporet på NM, men indtil videre uden held. Mange har bistået, David Robinson, Peter Steen Henriksen, Charlie Christensen, og ikke mindst Susanne Klingenberg, som i flere om- 
gange har kigget efter dem - tak til dem alle. Inger Hildebrandt fra forsøgscentret i Lejre har givet oplysninger om keramiks overgang til plastisk form. Med hensyn til spørgsmål i forbindelse med forkulning af tømmeret har Dan Blume og Brian W. Jensen, Dansk Brand- og Sikringsteknisk Institut været til stor hjælp, og det samme gælder Per Bjørnholt fra RMG-Inspektion og Niels Krüger fra Aarhus Brandvæsen, også tak til dem.

4. Eriksen og Olesen 2002, s. 60.

5. Mundtlig oplysning fra keramiker Inger Hildebrandt, Historisk-Arkæologisk Forsøgscenter, Lejre.

6. Bestemt af Jacob Kveiborg, Moesgårds Konservering og Naturvidenskabelige afdeling. Rapport fra 5. januar 2012 foreligger.

7. Udgravningsberetningen, s. 10.

8. Udgravningsberetningen, s. 14.

9. Webley 2008, s. 44f, fig. 4.2 .

10. Bestemt af Peter Hambro Mikkelsen, Moesgårds Konservering og Naturvidenskabelige afdeling. Rapport fra 12. juni 2012 foreligger.

11. Nielsen 1971, s. 9.

12. Nielsen 1971, s. 8.

13. Udgravningsberetningen, s. 25 (5231x83).

14. Hatt 1957, s. 250ff.

15. Becker 1961, s. 86 og 90.

16. Mundtlig meddelt fra Dan Blume og Brian W. Jensen, Dansk Brand- og Sikringsteknisk Institut, Per Bjørnholt, RGM-Inspektion og Niels Krüger, Aarhus Brandvæen.

17. Hansen 2007, s. 33 f.

18. Haarnagel 1984, 172; Kaul 1986, s. $177 f$.

19. Hatt 1953, s. 4ff, fig. 3 og 12.

20. Udgravningsberetningen, s. 34.

21. Eriksen og Olesen 2002, s. 60.

22. Webley 2008, s. 52, fig. 4.4 .

23. Hatt 1957, Plate II.

24. Rindel 1997, bd. 1, s. 217ff; Eriksen og Olesen 2000, s. $139 f$.

25. Jensen 1974, s. 3 ff.

26. Rindel 1997, bd. 3a, s. 129.

27. Bjerg 2007, 41ff; Lund Hansen 1987, s. 43.

28. Eriksen og Olesen 2000, s. 133f; Rindel 1997, bd. 1, s. 223.

29. Hatt 1957, s. $234 \mathrm{ff}$.

30. Henriksen og Robinson 1994, s. $17 \mathrm{ff}$.

31. Henriksen og Robinson 1994, s. 30.

32. Brøndegaard 1979, Bind 2, s. 134-148.

33. Mose Jensen 2010, s. 105.

34. Udgravningsberetningen, s. 14.

35. Eriksen og Olesen 2002, s. 60.

36. Møller 2000, $45 f$.

37. Rasmussen 1957, s. $341 \mathrm{ff}$.

38. Hatt 1953, s. 15.

39. Udgravningsberetningen, s. 14.

40. Dalsgaard m.fl. 2000.

41. Odgaard 2000, s. 28ff. 
42. Hatt 1953, s. 15.

43. Liversage og Robinson 1995, s. 42 f.

44. Møller 2000, s. 44, fig. 29.

45. Hatt 1942, s. 323.

46. Møller 2000, s. 41f.

47. Jensen 1974, s. 6.

48. Hatt 1957, s. 205.

49. Hatt 1953, s. 18 f.

50. Nielsen 2002, s. $5 \mathrm{ff}$.

51. Nielsen 1996, s. $57 f$.

52. Bl.a. Webley 2008, s. $149 f$.

\section{LITTERATUR}

Andersen, H. 1951: Et landsbyhus på Gørding Hede - Om huskonstruktion i tidlig middelalder. Kuml, s. 40-63.

Becker, C.J. 1961: Førromersk Jernalder i Syd- og Midtjylland. Nationalmuseets Skrifter, 6. København.

Bjerg, L. 2007: Romerske denarfund fra jyske jernalderbopladser. En arkcoologisk kulegravning. Aarhus.

Brøndegaard, V.J. 1979: Folk og Flora. Dansk Etnobotanik. Bind 1-4. København.

Eriksen, P. og L. Helles Olesen 2002: Fortiden set fra himlen. Holstebro.

Eriksen, P. og L. Helles Olesen 2000: Jernalderen. I: K. Dalsgaard, P. Eriksen, J.W. Jensen og J.R. Rømer (red.): Mellem Hav og Hede. Landskab og bebyggelse i Ulfborg herred indtil 1700. Aarhus, s. 125-143.

Haarnagel, W. 1984: Siedlungen. I: G. Kossack, K.-E. Behre og P. Schmid (Hrsg.): Archäologische und naturwissenschaftliche Untersuchungen an Siedlungen im deutschen Küstengebiet. Band 1, Ländliche Siedlungen Acta humaniora. Weinheim, s. 167-193.

Hansen, H.-O. 2007: I: M. Rasmussen (ed.): Iron Age Houses in Flames. Testing house reconstruction at Lejre. Studies in Technology and Culture, vol. 3. Lejre, s. 32-41.

Hansen, U. Lund 1987: Römischer Import im Norden. Nordiske Fortidsminder, Serie b, Bind 10. København.

Hatt, G. 1942: En sænket og hævet Jernalderboplads ved Ringkøbing Fjord. Svenskt Geografisk Årsbok, s. 314-329.

Hatt, G. 1953: An Early Roman Iron Age Dwelling Site in Holmsland, West Jutland. Acta Archaeologica XXIV, s. 1-25.

Hatt, G. 1957: Nørre Fjand. An Early Iron Age Willage Site in West Jutland. Arkæologiskkunsthistoriske Skrifter, bind 2, no 2. Videnskabernes Selskab. København.

Haue, N. 2011: Social stratifikation og den "sociale arv" i ældre jernalder med udgangspunkt i bopladsstudier fra Nordjylland. I: N.A. Møller, S.S. Qvistgaard \& S.F. Jensen (red.): Nyt fra Vestfronten. Nord- og vestjyske bebyggelser fra aldre Jernalder. København.

Henriksen, P.S. \& D. Robinson 1994: AEldre jernalders agerbrug; arkcobotaniske analyser af kornfundene fra Overbygård, Østerbølle, Fjand og Alrum. NNU Rapport nr. 12. København.

Jensen, P. Mose, Marianne Høyem Andreasen og Peter Hambro Mikkelsen 2010: Bulbous oat grass - A magic plant in prehistoric Jutland and Fünen. I: C. Bakels, K. Fennema, W.A. Out og C. Vermeeren (eds.): van Planten en Slakken. Festskrift til Wim Kuijper. Leiden, s. 103-114. 
Jensen, J. Aarup 1974: Huse i havstokken. Skalk, nr. 6, s. 3-9.

Kaul, F: 1986: Priorsløkke: en befæstet jernalderlandsby fra ældre jernalder ved Horsens. Nationalmuseeets Arbejdsmark, s. 172-183.

Kveiborg, J. 2012: Kursorisk gennemgang af knogler fra RIM 5231 Alrum (FHM 4296/88). Rapport fra Moesgårds Konserverings- og naturvidenskabelig afdeling, 5. januar 2012. Højbjerg.

Liversage, D. og D. Robinson 1995: Prehistoric Settlement and Landscape Development in the Sandhill Belt of Southern Thy. Journal of Danish Archaeology, vol. 11, 1992-93 (1995), s. 39-56.

Mikkelsen, P. Hambro 2012: Gennemgang af forkullet materiale fra RIM 5231 Alrum (FHM 4296/88). Rapport fra Moesgårds Konserverings- og naturvidenskabelig afdeling, 12. juni 2012. Højbjerg.

Møller, J. Thyge 2000: Engang en del af havet: Fjorde og søer i Ulfborg herred. I: K. Dalsgaard, P. Eriksen, J.W. Jensen \& J.R. Rømer (red.): Mellem Hav og Hede. Landskab og bebyggelse i Ulfborg herred indtil 1700. Aarhus, s. 36-58.

Nielsen, B.H. 1996: Smedegård - en byhøj fra den ældre jernalder ved Nors. Historisk Arbog, Thy og Vester Hanherred, s. 51-60.

Nielsen, J.N. 1971: Det utrolige fra Thy. Skalk, nr. 6, s. 7-10.

Nielsen, J.N. 2002: Flammernes bytte. Skalk, nr. 6, s. 5-10.

Odgaard, B. 2000: Fra skov til hede: Vegetationens historie i Ulfborg herred. I: K. Dalsgaard, P. Eriksen, J.W. Jensen og J.R. Rømer (red.): Mellem Hav og Hede. Landskab og bebyggelse i Ulfborg herred indtil 1700. Aarhus, s. 28-35.

Rasmussen, H. 1957: Fishing at Nørre Fjand. I: G. Hatt: Nørre Fjand. An Early Iron Age Willage Site in West Jutland. Arkæologisk-kunsthistoriske Skrifter, bind 2, no 2. Videnskabernes Selskab. København, s. 341-360.

Rindel, P.O. 1997: Grøntoft - og etableringen af det strukturerede landsbysamfund $i$ Vestjylland $i 1$. artusinde f.Kr. Bind 1-3. Ph.d.-afhandling. Institut for Arkæologi og etnologi, Københavns Universitet.

Webley, L. 2008: Iron Age Households. Structure and practice in Western Denmark, 500 BC-AD 200. Jutland Arschaeological Society Publications, vol. 62. Højbjerg. 


\section{Alrum}

\section{Burnt houses at an Early Iron Age tell site in Western Jutland}

The Alrum settlement is renowned in particular for producing one of the largest prehistoric finds of charred grain and seeds ever discovered in Denmark.

The site was excavated in 1939 under the direction of Gudmund Hatt, but it was Hans Helbæk who carried out a detailed analysis of the plant remains. The latter were subjected to re-examination in 1994, whereas the extensive finds assemblage, stored at Ringkøbing Museum, has only now been fully investigated and analysed. The reason for this is that the excavation records, thought for many years to have been lost, turned up by chance at the National Museum of Denmark in 2000.

The Alrum site is located on a slight elevation, about $1 \mathrm{~km}$ from Stadil Fjord and $10 \mathrm{~km}$ north of the town of Ringkøbing (fig. 1).

\section{The settlement}

The excavation trench exposed an area of about $300 \mathrm{~m} 2$, within which there were sequences of six to seven house sites lying one on top of the other, resulting in cultural deposits with a vertical stratigraphy of $1.5 \mathrm{~m}$, in other words a tell site (fig. 2). Two of the houses (house I and house II) had been destroyed by fire and had been abandoned in such great haste that everything remained within the burnt-out remains of the buildings. House II was the better preserved of the two, containing building timbers, c. 50 pottery vessels, straw ropes, some stone tools, a ball of wool etc. The house was $14.5 \mathrm{~m}$ long and $4.5 \mathrm{~m}$ wide (c. $60 \mathrm{~m} 2)$, with living quarters at the western end and a presumed byre to the east. Relative to contemporary houses in Eastern Jutland, those in Western Jutland were small. The roof was borne by five pairs of posts arranged along the length of the house and was probably comprised of heather turf. The post-built walls had an inner cladding of thick oak planks, whereas the outer surface is presumed to have been covered with a layer of straw or grass. The living quarters were fitted out with a clay bench or platform at the gable, an ornamented hearth in the middle and, between the two, a stone mortar set firmly into the clay floor (fig. 3). No traces were seen in the byre of the usual stall dividers, so perhaps the house had not been fully completed when the fire broke out! Most of the pottery lay close to the clay bench, together with several bodies of untempered clay; these weighed c. $9 \mathrm{~kg}$. Up against the north wall there were two impressive solid andirons, $27-28 \mathrm{~cm}$ in height and weighing more than $3 \mathrm{~kg}$ (figs. 4, 5, 6, 7 and 8 ). The pottery dates the house to the late Pre-Roman Iron Age.

Beneath house II lay the successive remains of six to seven other houses. The pottery reveals that this small village was founded around $500 \mathrm{BC}$, whereas the latest examples are from the century around the birth of Christ (figs. 6 and 13). Only parts of house I could be excavated, but here too a great deal of pottery was encountered, together with a few stone artefacts (figs. 9 and 11).

\section{Building timber}

Virtually all the woodwork in the burnt houses was of oak, supplemented by a little 
willow and alder which are well suited to making the wattle of the walls. In each house there was a large number of roof and wall postholes, with the charred post ends still in situ; along the walls lay large pieces of so-called wattle panels. As a consequence, it was possible to measure the dimensions of the timbers. Charring leads to a reduction in size of the timber, but by how much? Information received from the Danish Institute of Fire and Security Technology states that, as a rule of thumb, there is a reduction of $0.5-0.6 \mathrm{~mm}$ for every minute the fire burns. Figure 10 gives the timber dimensions alongside a column showing measurements after 20 minutes of burning, to which $1 \mathrm{~cm}$ has been added. In spite of the latter, the timber dimensions were still markedly less than those of unburnt posts seen at for example Feddersen Wierde in the North German salt marshes. As oak is totally dominant as the building timber, this begs the question as to where it was obtained? A pollen diagram from a site located $4-5 \mathrm{~km}$ from Alrum shows that the landscape was open and unlikely to have had large areas of oak woodland. One possibility is that the oak wood was obtained from Eastern Jutland, perhaps being exchanged for fish and other marine resources?

\section{Agriculture and fishing}

The large quantities of charred grain and seeds recovered from the site constitute an excellent basis on which to gain a detailed insight into the subsistence. The most important cereals were barley and oats, accompanied by a little wheat, flax and gold of pleasure. In addition to these, seeds had been gathered from a range of weedy species, with corn spurrey, goosefoot, and persicaria being the commonest (fig. 14). These weeds show that the arable fields were sandy and only lightly manured and this conclusion is supported by the size of the cereal grains which is also very modest. It seems likely that the low-lying fields were flooded with salt water from time to time, but barley, flax and gold of pleasure are all salt tolerant.

In historical times seeds of the above weed species were used in bread, porridge and gruel by farmers living on the Jutland heath. Tubers of false oat grass were also found at Alrum; these are rich in starch and therefore represent a good food supplement. The heaps of crop plant remains can be classified as threshed and unthreshed (fig. 15). This can perhaps give an indication of the time of year at which the fire took place; it was most probably in the autumn. On the other hand, the bone material from the site is very limited due to the well-drained acid sandy soil. Mention can, however, be made of a perforated ox astragalus (fig. 11a-b). Even so, it can safely be presumed that the many good grazing areas were extensively exploited.

On the basis of the site's location and finds of stone net sinkers, it seems justified to refer to Alrum's inhabitants as fisherfarmers.

\section{Settlement and landscape}

Today, the Jutland west coast has a harsh climate with sand drift and storms as significant factors in the lives of the inhabitants. But this was not always the case and in the Early Iron Age the situation must have been quite different: Sand drift was less extensive, the coastline had a different appearance and the sea level fluctuated, as can be seen for example at Højbjerg just south of Ringkøbing Fjord and in several other locations (fig. 1). A rise in sea level of just $0.5 \mathrm{~m}$ would reduce the area of shore meadow considerably (fig. 16). The woodland picture was also different.

The most important indicator of this very different landscape and environment is the sustained habitation which characterises many settlements, and is exemplified by Alrum with more than 500 years of activity at the same location, and even a further couple of centuries close by, as 
suggested by recent aerial photographs. People lived at Nørre Fjand for 300-400 years and Klegod, now located directly on the present-day coastline, was probably occupied for at least a century. Such extended occupation of the same site must also be presumed to have resulted in social and family-related changes.

There was of course some sand drift in the Early Iron Age. This is apparent from sand layers between the individual house phases and on the arable fields. However, it was apparently not so extensive that it prompted people to move; the sand layers are modest in their thickness. A good example of the stubbornness of these Iron Age people is seen at the small village of Klegod where the inhabitants ploughed through a layer of sandy soil of no less than $40 \mathrm{~cm}$ in thickness.

The course of the coastline must also have been quite different back then as remains of Iron Age settlements are revealed now and then by today's fierce winter storms which can cut deep into the sand dunes. Klegod, which dates from c. 500 $\mathrm{BC}$, is just such a locality and provides secure proof that the coast must have lain a good way out to the west at the time, perhaps as much as several kilometres.

In this dynamic and changeable landscape, the fisher-farmers of the Early Iron Age managed to maintain their existence over many generations and they were perhaps not as isolated as one could easily imagine. However, one main question remains: What led these people to settle in these near-coastal areas? The numerous Iron Age sites show that many families must have been involved. Was it marine resources or the good grazing along the shore meadows which attracted them? Another factor should also be pointed out: The coastline also hosted an archipelago, with a protective row of islands located offshore as seen today in the Netherlands and Northern Germany and these provided opportunities for closer contacts with the latter areas.

Jørgen Lund \& Poul Nissen Moesgård Museum 